\title{
A Summary of Information on the Rust Puccinia psidii Winter (Guava Rust) with Emphasis on Means to Prevent Introduction of Additional Strains to Hawaii
}

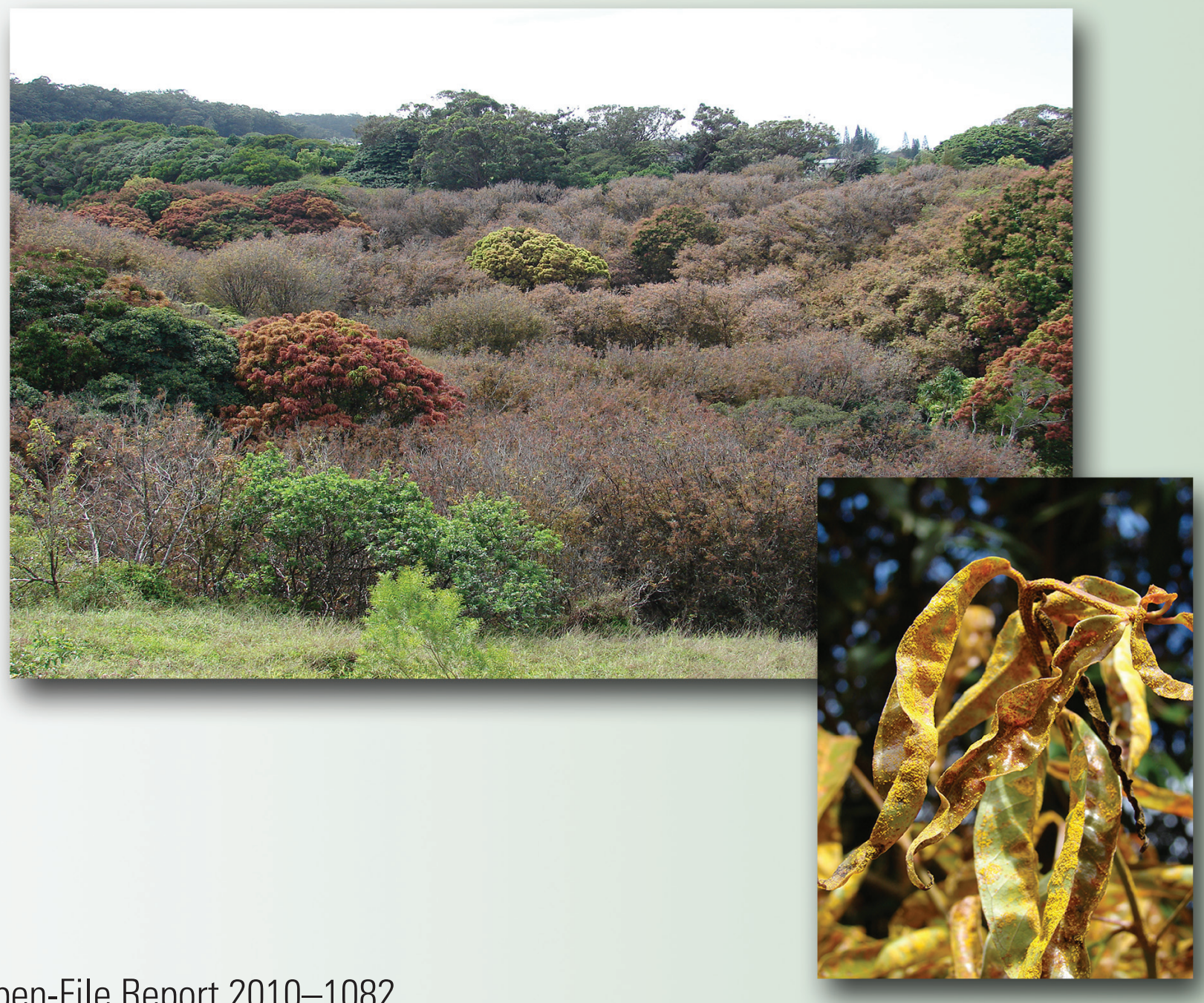

Open-File Report 2010-1082 
COVER:

A stand of rose apple (Syzygium jambos) on a roadside in Haiku, Maui, Hawaii, March 2008, after new leaf growth had been largely exhausted. Inset shows closeup of rose apple leaves in the same area covered with spores of the rust Puccinia psidii in April 2007, when new growth was still being produced prolifically. The stand has been repeatedly defoliated by the single genotype of Puccinia psidii, the neotropical rust fungus that was first noted in Hawaii in April 2005. Other genotypes of the rust that attack rose apple mildly or not at all apparently exist in Puerto Rico and elsewhere. Both photos by Forest and Kim Starr, used with permission. 
Pacific Island Ecosystems Research Center

\section{A Summary of Information on the Rust Puccinia psidii Winter (Guava Rust) with Emphasis on Means to Prevent Introduction of Additional Strains to Hawaii}

By Lloyd Loope

Open-File Report 2010-1082 


\section{U.S. Department of the Interior \\ KEN SALAZAR, Secretary}

\section{U.S. Geological Survey Marcia K. McNutt, Director}

\section{U.S. Geological Survey, Reston, Virginia: 2010}

This report and any updates to it are available online at:

http://pubs.usgs.gov/of/2010/1082/

For product and ordering information:

World Wide Web: http://www.usgs.gov/pubprod

Telephone: 1-888-ASK-USGS

For more information on the USGS — the Federal source for science about the Earth, its natural and living resources, natural hazards, and the environment:

World Wide Web: http://www.usgs.gov

Telephone: 1-888-ASK-USGS

Any use of trade, product, or firm names is for descriptive purposes only and does not imply endorsement by the U.S. Government.

Although this report is in the public domain, permission must be secured from the individual copyright owners to reproduce any copyrighted materials contained within this report. 


\section{Contents}

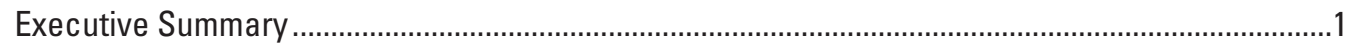

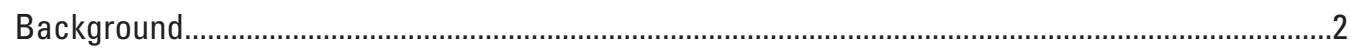

Importance of Ohia for Native Ecosystems and Biota and Implications of

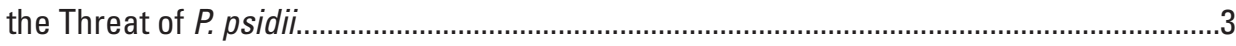

Significance and Status of Hawaii's Native Biota-A Very Brief Introduction..........................

Metrosideros polymorpha as a Foundation Species in the Hawaiian Ecosystem .................... 4

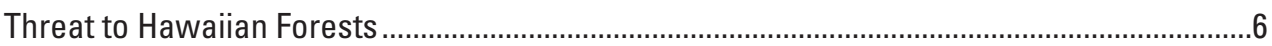

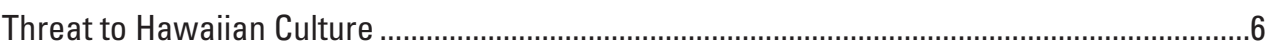

Threat to Hawaiian Fauna, Including Hawaiian Honeycreepers.............................................6

Threat to Nioi, Eugenia koolauensis, a Federally Endangered Plant Species.............................6

A Note on Terminology Below the Species Level ....................................................................

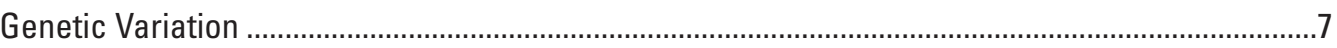

Potential Impacts of Different Strains on Host Parasite Interactions .......................................

Known Genetic Variation in P. psidii ....................................................................................

A Molecular Diagnostic Test for P. psidii ...................................................................................

Indirect Evidence of the Existence and Consequences of Genetic Variation in P. psidii .........8

Direct Evidence from the Literature that Multiple Strains or Races of $P$. psidii Exist .............10

Evidence that Hawaii's "Strain" of $P$. psidii is Different from Other Populations-Baseline

Characterization of the Host Range of $P$. psidii in Hawaii, 2005-2008 .........................11

Sexual Recombination or Lack Thereof in Puccinia psidii ....................................................14

Potential for Additional Genotypes/Strains of P. psidii and Other Serious Pests to Arrive and

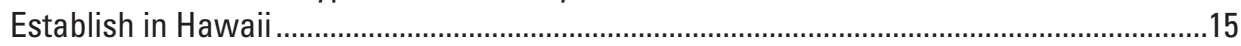

What are the Potential Pathways for Entry of $P$. psidii into Hawaii? .......................................15

The Myrtaceae Flower/Foliage Pathway and P. psidii.......................................................16

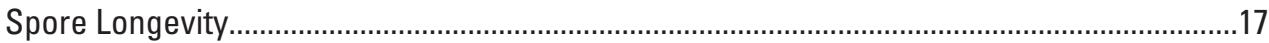

Potential for Urediniospores of $P$. psidii on Foliage or Flowers to Establish a Population in Hawaii.........................................................................................................

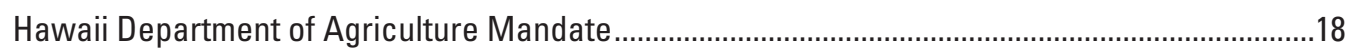

Regulatory Options ........................................................................................................... 18

Expected Economic Impacts of Stringent Regulation of the Myrtaceae Pathway ................20

Existing Framework for Addressing this Rust and an Available Option..................................20

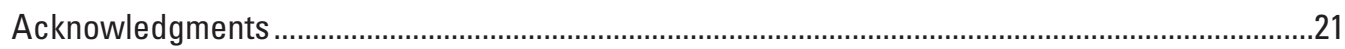

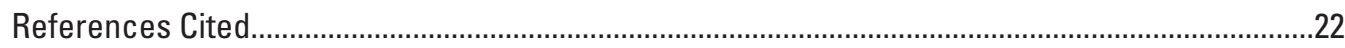

Appendix. Sketches of Risk Assessments for Selected Insect Pests and Pathogens that Pose Significant Threats to Native and (or) Nonnative Myrtaceae in Hawaii..............................29

1. Trioza eugeniae Froggatt, Eugenia Psyllid ...................................................................29

2. Chrysophtharta m-fuscum Boheman, Eucalyptus Tortoise Beetle....................................29

3. Leptocybe invasa Fisher and LaSalle, Blue Gum Chalcid (Hymenoptera: Eulophidae)....30

4. Mycosphaerella molleriana (Thum.) Lindau ("Crinkle Leaf Disease") (Ascomycota: Mycosphaerellales: Mycosphaerellaceae) …………….............................................30

5. Neofusicoccum parvum (Pennycook and Samuels) Crous, Slippers and A.J.L. Phillips (Ascomycota: Botryosphaeriales: Botryosphaeriaceae)... 
This page left blank intentionally. 


\title{
A Summary of Information on the Rust Puccinia psidii Winter (Guava Rust) with Emphasis on Means to Prevent Introduction of Additional Strains to Hawaii
}

\author{
By Lloyd Loope
}

\section{Executive Summary}

The neotropical rust fungus Puccinia psidii (P. psidii) was originally described from the host common guava in its native Brazil but has been found since on hosts throughout the myrtle family (Myrtaceae), including a dramatic host jump to nonnative Eucalyptus plantations. Most rust fungi are able to live only on a very narrow range of host species. P. psidii is unusual both for having a broad host range and for the intensity of its damage to susceptible young growth. This rust first got a foothold in the United States in Florida more than three decades ago. The U.S. Department of Agriculture (USDA) has since considered it a nonactionable, nonreportable pest. Hawaii and Florida are the only two states with native species in the myrtle family. Over a period of 30 years, this rust has done little damage to any of the scattered native Myrtaceae in Florida, although the host range of the rust has gradually grown to about 30 mostly nonnative species in the family, apparently because of increasing genetic variety of the rust by repeated introductions. However, Florida's native Myrtaceae are among the roughly 1,100 neotropical species that are largely resistant to $P$. psidii. The 3,000 species of non-neotropical Myrtaceae of the Pacific, Australia, Asia, and Africa are expected to prove much more vulnerable to P. psidii. Little is known about the genetics or genetic strains of $P$. psidii, although existing literature shows that there are numerous strains that have differential ability to infect suites of host plants.

The rust was first recorded in the state of Hawaii on Oahu in April 2005 and quickly spread throughout the Hawaiian Islands. The main concern in Hawaii became the potential threat to ohia, Metrosideros polymorpha (Myrtaceae), the endemic forest tree species overwhelmingly important in Hawaii's nature and culture. The potential ecological consequences of a virulent strain of rust on ohia forests are immense, due to its role as a foundation tree species and the diversity of niches it fills in Hawaii.

A single genetic strain of the rust is established in Hawaii, apparently composed of a single genotype lacking sexual reproduction. P. psidii has been found statewide in Hawaii attacking Myrtaceae from near sea level to about 1,200 m elevation in areas with rainfall ranging from $750-5,000 \mathrm{~mm}$. Five of eight native Myrtaceae and at least 15 nonnative species have been observed as hosts of $P$. psidii in Hawaii. The federally endangered Eugenia koolauensis (nioi) and the nonendangered indigenous species Eugenia reinwardtiana are severely damaged. The introduced (an Asian species) and invasive rose apple, Syzygium jambos, is severely affected at a landscape scale, with widespread crown dieback and many instances of complete tree death. In spite of billions of wind-dispersed rust spores produced from rose apple infestations during 2006 to 2008, adjacent ohia have been little affected to date by the rust strain in Hawaii. Within the elevation range of the rust, P. psidii is found on less than 5 percent of the ohia trees in the wild; on those ohia trees on which the rust is found, it is normally found on less than 5 percent of the leaves.

The strain in Hawaii has not attacked many of the species known to be infected by the rust elsewhere, including common guava. On the basis of the very substantial genetic diversity of the much-studied, crop-damaging species of the genus Puccinia, there is good reason to believe that there are at minimum dozens and likely hundreds or thousands of genotypes of $P$. psidii, likely concentrated in the core range in Brazil but with potential for dispersal by globalization. Multiple genotypes are believed already present in the United States and certain to spread freely in the absence of restrictions. The U.S. Forest Service has initiated a major collaborative project in Brazil to investigate the genetics of susceptibility of Hawaii's ohia to P. psidii, but initial results will likely not be available for several years. If just one more strain reaches Hawaii, the consequences could be dire for ohia, with each new genotype arriving having an unknown likelihood of increasing damage to ohia; possibilities for mutation and (or) genetic mixing, even with asexual strains, are apparently substantial, based on what is known about other Puccinia species. Investigations are needed to clarify rust-nioi relationships. However, it is likely that keeping out new strains of $P$. psidii may be important for long-term survival of nioi as well as for the health of ohia forest.

The source of Hawaii's initial invasion by P. psidii is uncertain but is strongly suspected to have been decorative 
foliage of species in the myrtle family from the mainland United States, most likely California, where there had been outbreaks of this rust on cultivated myrtle in 2005. In 2006-7, Maui's Hawaii Department of Agriculture (HDOA) inspectors intercepted several P. psidii infected shipments of foliage myrtle, shipped from several California counties. Recognizing the huge threat of the rust to Hawaii's one million acres of ohia forests, and consequently to Hawaii's watersheds and biodiversity, Hawaii's Board of Agriculture unanimously approved an interim rule in August 2007 banning importation of plants in the myrtle family from "infested areas," specified as South America, Florida, and California. However, the interim rule has not been made permanent by HDOA, and the department has stated that it needs further information to formulate a longterm rule that imposes appropriate measures.

Rust spores can survive for 2 to 3 months, and the pathogen can be transported to Hawaii on Myrtaceae from anywhere in the world through the United States mainland. There is much geographic reshuffling of flowers and foliage among the far-flung firms in the trade, especially for bouquet making. Because $P$. psidii is a nonactionable and nonreportable pest in the United States, foliage and flowers of the myrtle family can move freely into the country (usually but not necessarily always through the ports of Miami or Los Angeles), and from state to state.

Currently, the State of Hawaii regulates incoming plant material in the family Myrtaceae by visual inspection. Inspection capacity and latent (asymptomatic) infections limit the ability to detect the rust. New molecular tests could improve detection efficiency, but the cost and the time required to process samples currently precludes their routine use in ports of entry. Interdiction, which has effectively kept coffee rust (Hemileia vastatrix) out of Hawaii for 120 years, offers the strongest protection for Hawaii's native ecosystems from $P$. psidii. Interdiction of Myrtaceae from the continental United States could have the important supplementary benefit of preventing establishment in Hawaii of other very significant pests of multiple species of Myrtaceae that are already in the country, including: the Eugenia psyllid Trioza eugeniae (Hemiptera: Psyllidae); Chrysophtharta m-fuscum, the Eucalyptus tortoise beetle (Coleoptera: Chrysomelidae); Leptocybe invasa, the blue gum chalcid wasp (Hymenoptera: Chalcidae); and the fungal pathogens Mycosphaerella molleriana (Ascomycota: Mycosphaerelliaceae, crinkle leaf disease of Eucalyptus spp.) and Neofusicoccum parvum (Ascomycota: Botryosphaeriaceae), currently causing serious damage to Syzygium paniculatum in south Florida nurseries. Each of these pests would be likely to cause very significant damage to native and (or) cultivated Myrtaceae in Hawaii. Each of these pests is a prime candidate for transport by the foliage and (or) nursery stock pathways from Florida and California into Hawaii.

Hawaii Department of Agriculture has a clear mandate to protect Hawaii's natural environment, forestry and cultivated Myrtaceae. Principles of the World Trade Organization's Treaty on Sanitary and Phytosanitary Measures and the International Plant Protection Convention are consistent with the right of Hawaii to take action. The current threat of $P$. psidii and the other five serious threats to Myrtaceae are primarily posed by the importation of infected plants from the continental United States; however, that may change in the future. If Hawaii were to decide to take a stand (through State regulation) to protect its native and introduced Myrtaceae, there is a possibility that USDA would consider Federal regulation of Myrtaceae from foreign countries.

\section{Background}

Brasier (2008, p.792) has described the general problem of which $P$. psidii and a rapidly increasing number of other plant pathogens are part:

As native, locally adapted plant communities evolved, guilds of unique pathogenic microorganisms, viruses and viroids evolved in association with them. Today these organisms often cause little noticeable damage to their host plants, having developed a natural balance through co-evolution. However, major problems may arise if a pathogen escapes - or is introduced - to another region of the world where the native plants have little resistance and the pathogen has eluded its natural enemies. Such events can trigger damaging disease episodes that may also have long-term negative impacts on the environment, economy and cultural heritage. Movement of plants and plant products between biogeographical zones by human activities is now generally accepted to be the primary mode of introduction of exotic pathogens and pests.

The rust fungus Puccinia psidii Winter was originally described from common guava (Psidium guajava) in eastern Brazil in 1884. It became notorious for its host jump to nonnative Eucalyptus, first observed in Brazil in the 1940s; it caused substantial economic damage to large Brazilian timber plantations in the 1970s (Coutinho and others, 1998). The host jump in Brazil is currently cited as a prime example in the literature illustrating the potential danger for host jumps following anthropocentric movement of potential hosts (Wingfield and others, 2001, Slippers and others, 2005). The original native range of the rust in the Americas is uncertain. Until recently, $P$ psidii was "known only from South America, mainly east of the Andes, including northern-most Argentina, Uruguay, Paraguay, Brazil, Venezuela, Ecuador, and Colombia; Central America and the Caribbean, including Cuba, Dominican Republic, Jamaica, Puerto Rico, Trinidad and Tobago; and Florida in the United States" (Tommerup and others, 2003).

Puccinia psidii is well known to have a broad host range in the Myrtaceae, one of the largest plant families in the world, with most species in the tropics and Southern Hemisphere. The 1,100 species of Myrtaceae in South and Central America have presumably evolved with this rust and are only mildly susceptible or not at all; only about 30 of them have been 
recorded as infected by the rust to date (Simpson and others, 2006). Based on the hosts affected by P. psidii in Hawaii to date, we suspect that, in contrast, many of the $3000+$ Myrtaceae native outside the Neotropics and subtropics will prove to be susceptible hosts, likely ranging from mildly to disastrously susceptible to some part of the genotypic spectrum of P. psidii. Hawaii has four or eight native species (depending on which taxonomic approach one accepts) of Myrtaceae and about 200 nonnative species, nearly half of which are in the genus Eucalyptus.

This rust first occurred in the United States in Florida in the mid-1970s, where it damaged allspice (Pimenta dioica) (Marlatt and Kimbrough, 1979), as it had earlier done in Jamaica (MacLachlan, 1938). Because the rust was already established in the United States and was not under control, the U.S. Department of Agriculture (USDA), Animal and Plant Inspection Service (APHIS), has since the 1970s considered it a nonactionable, nonreportable pest nationally. Scientists have suggested that repeated introductions of the pathogen from outside Florida have apparently increased the genetic variability of the rust, making increasing numbers of species vulnerable to infection in that State over three decades (for example, Leahy, 2004). However, damage to the dozen native species of Myrtaceae in Florida seems to have been minor, consistent with the observation by Simpson and others (2006) that damage caused by the rust is generally minor among neotropical species of Myrtaceae.

Then in April 2005, P. psidii was suddenly detected in Hawaii (Killgore and Heu, 2005), its first invasion of a region with completely unexposed native Myrtaceae. Differences in the behavior of the new rust population from that of other populations reported in the literature were immediately obvious; for example, extensive stands of common guava, the species with which the rust was most associated in its home range in Brazil, were unaffected in Hawaii. Several endemic species of Myrtaceae in Hawaii were negatively affected, most notably ohia (Metrosideros polymorpha) and the federally endangered Eugenia koolauensis. Ohia, overwhelmingly dominant over 400,000 ha of native forest in Hawaii, was affected mildly in the wild (more so in nurseries and cultivation), whereas E. koolauensis was affected severely. Recognizing the threat of $P$. psidii to Hawaii's Metrosideros forest, Loope and La Rosa (2008) prepared an analysis of risk of introduction into Hawaii of additional strains of the rust. In August 2007, the Hawaii Board of Agriculture recognized the threat of the rust to Hawaii's ohia forests and to Hawaii's watersheds and unique biodiversity. The Board unanimously approved a 12-month interim rule banning importation of plants in the myrtle family from "infested areas," specified as South America, Florida, and California. However, the interim rule was not made permanent by Hawaii Department of Agriculture (HDOA) and expired in August 2008. Meanwhile, an official in APHIS had confirmed to HDOA that the agency considers $P$. psidii a nonactionable, nonreportable pest, and therefore it would not be kept out of Hawaii if intercepted at the border coming from a foreign country. If that APHIS verdict is to change, there is said to be a need to demonstrate that multiple strains or races of $P$. psidii exist and that there is no practical way of distinguishing new, potentially more virulent strains, from the one already present in Hawaii (Dorothy S. Alontaga of APHIS in an email to Anne-Marie La Rosa of USDA Forest Service, January 4, 2008). Given its interpretation of APHIS guidelines and the possibility of challenge from California interests, HDOA's leadership has stated that it feels the need for a more rigorous analysis (than Loope and La Rosa, 2008) to evaluate the options and their justification (Carol Okada and Lyle Wong, HDOA, oral commun. 2009). This analysis responds to that need.

\section{Importance of Ohia for Native Ecosystems and Biota and Implications of the Threat of $P$. psidii}

\section{Significance and Status of Hawaii's Native Biota-A Very Brief Introduction}

Kaneshiro (1989) addressed the uniqueness of Hawaii’s biota:

Hawaii has often been referred to the best "natural laboratory" for evolutionary studies in the world... [E]volutionary studies of Hawaii's native biota have been extremely important in developing modern theories of speciation and evolution. Such studies are second to none. What is even more important is the fact that Hawaiian ecosystems present a unique opportunity to investigate basic biological phenomena for so many different subdisciplines of biology. However basic such research may be, the knowledge gained will be applicable to more mission-oriented research programs ... The single most important resource of Hawaii is its native biota. The commitment of State and Federal agencies to implement stringent conservation and management policies is vital to its preservation.

Cowie and Holland (2008) described the physical setting of the Hawaiian islands and its implications:

The Hawaiian archipelago . . . consists of a sequence of oceanic islands formed as the Pacific plate moves north-westwards over a stationary plume or 'hot spot' in the Earth's mantle, which periodically sends magma up through the plate, creating a chain of volcanoes, each sequentially younger than the one that preceded it, and that will have moved northwestwards away from the hot spot. Eventually, each island subsides and erodes, becoming a low atoll, then a submerged seamount, and is finally subducted 
as the Pacific plate slides under the adjacent tectonic plate (Price \& Clague 2002) .... .

The biodiversity and evolutionary radiations of the Hawaiian Islands are arguably more spectacular than those of the Galapagos .... [T] [Te biological radiations of the Hawaiian Islands have come to be considered some of the paramount examples of natural evolutionary experiments (Simon 1987), in which replicate clades on sequentially produced and precisely dated islands have lent major insights into many aspects of evolutionary biology including speciation ..., biogeography . .., sexual selection $\ldots$, and ecosystem processes ....

Hawaii's 4,000 km separation from the nearest large landmass and 1,600 km distance from the nearest neighboring island group has posed a formidable barrier to colonization by terrestrial organisms. Nevertheless, the archipelago has 956 native angiosperm species, representing radiation from about 256 founding species, most of which arrived from the south and west during the past 5 million years (Fosberg, 1948; Price and Clague, 2002; Price and Wagner, 2004). For example, the tiny seeds of the ancestor of ohia were apparently superbly adapted for highly effective dispersal by air currents over long distances and able to survive periods of immersion in saltwater (Percy and others, 2008).

The scientific fame of Hawaii's biota is matched by its vulnerability to invasion and extinction. Habitat destruction and invasive species have taken a serious toll (Cuddihy and Stone, 1990). Howarth and others (1988) addressed this issue in a leadoff article in an issue of the journal BioScience in April 1988 devoted to "Hawaii's evolutionary biology":

Hawaii has lost so much natural diversity since the arrival of humans ... that one might despair that nothing is left worth saving. Two-thirds of the bird species, including all the flightless species; over one-half of the endemic snails; and untold numbers of insects have already been lost. About 30 percent of the native flora . . . are endangered species candidates. Against these odds, does any native species have a chance to survive? The resilience displayed by the surviving native species provides an optimistic answer.

Recent biological discoveries, including new species and new concepts in evolution and ecology ... should reinforce the conviction that native Hawaiian biota deserves protective management. Recent research and management actions in national parks, nature conservancy reserves, and national wildlife refuges demonstrate that native species benefit from appropriate conservation programs and that conservation of the remaining native biota is possible.

Over the past 20 years, what was once a theoretical threat of global climate change to Hawaii has been confirmed. Loope and Giambelluca (1998) predicted the possibility of an unfavorable scenario:
Island tropical montane cloud forests may be among the most sensitive of the world's ecosystems to global climate change. Measurements in and above a montane cloud forest on East Maui, Hawaii, document steep microclimatic gradients. Relatively small climate driven shifts in patterns of atmospheric circulation are likely to trigger major local changes in rainfall, cloud cover, and humidity. Increased interannual variability in precipitation and hurricane incidence would provide additional stresses on island biota that are highly vulnerable to disturbance related invasion of nonnative species.

There are as yet no signs of increase in hurricane incidence, but in the past three decades, temperature at high elevations in Hawaii has increased $0.8^{\circ} \mathrm{C}$ (Giambelluca and others, 2008). Pratt and others (2009) discuss implications for Hawaii's forest bird habitat, which lies almost entirely in Metrosideros forest:

Today, native forest birds face climatic changes unprecedented both in magnitude and speed. Current models predict an overall temperature increase in the tropics of about 2 to $3^{\circ} \mathrm{C}$ by the year 2100 (Neelin and others, 2006), and in fact increases in mean temperature have already occurred in Hawai' i (Giambelluca and Luke, 2007) ... . In the main Hawaiian Islands, predicted changes associated with this temperature increase include a shift in vegetation zones upslope, changes in mean precipitation with unpredictable effects on local environments, increased occurrence of drought cycles, and increases in the intensity and number of hurricanes (Loope and Giambelluca, 1998). High elevation native forest bird habitats may experience dramatic change because they are located in cloud forests, just under the tropical inversion layer that controls the altitudinal limits of rainfall. Rainfall declines rapidly above the inversion layer, which is more important than temperature in determining the upper limit of montane rainforest on Maui and Hawai'i (Giambelluca and Luke, 2007). This zone experienced major shifts during prior cycles of climate change....

There is as yet no clear prognosis for the extent and impact of climate change on Hawaii and its native biota. A complicating factor is that climate in the Hawaiian Islands is extremely variable, with precipitation ranging from $250 \mathrm{~mm}$ to more than $10,000 \mathrm{~mm}$ and with temperature regimes ranging from tropical to alpine (Giambelluca and Schroeder, 1998).

\section{Metrosideros polymorpha as a Foundation Species in the Hawaiian Ecosystem}

Metrosideros polymorpha, Hawaii's dominant forest tree, is one of the best examples of a "foundation species," 
absolutely essential to forest ecosystem function and to the biodiversity that the forest harbors (for example, Ellison and others, 2005). Hawaii has lost roughly half of its original native forest, but 400,000 hectares of ohia-dominated forest currently remains.

Ohia (Myrtaceae: Metrosideros polymorpha GaudichaudBeaupré) is by far the most common and widespread native tree in the Hawaiian Islands.

Gruner (2004) stated (prior to arrival in Hawaii of P. psidii):

Metrosideros polymorpha is found on all the main islands, naturally occurs from sea level to tree line $(>2000 \mathrm{~m})$, in dry, mesic, and wet forests, and is the canopy dominant in old growth and the first woody colonist on recent basaltic lava flows .... Numerous insect species use ohia lehua as a resource for either food or habitat space, and it may have the largest fauna of any native plant .... Metrosideros is an important, year-round nectar resource for native bees, moths, thrips and other insects, and for native nectarivorous birds, such as the apapane (Himatione sanguinea), iiwi (Vestiara coccinea), and akohekohe (Palmeria dolei). Metrosideros also provides important habitat for birds that forage for arthropod prey in the foliage (e.g., akepa [Loxops coccineus]) and bark (e.g., Hawaii creeper [Oreomystis mana]). It can be argued that M. polymorpha is the backbone of Hawaiian forests and one of the most important resources for the long-term stability of ecosystems and watersheds in the islands.

According to recent work by Percy and others (2008), ohia has been evolving in the Hawaiian islands for nearly 4 million years and has become genetically adapted to diverse local environments. Derived (by way of the Marquesas Islands) from an ancestral species of Metrosideros that colonizes new lava flows in New Zealand, ohia was apparently able to outcompete most other plant species in precontact Hawaii and came to form the habitat matrix for the evolution of a large fraction of Hawaii's endemic flora and fauna. Although some other plant groups underwent complex adaptive radiation, vigorous gene flow apparently kept Hawaii's ohia from diversifying into multiple species. Although multiple species and varieties have been delineated and named by various botanists, the current consensus seems to be that there is a single highly polymorphic species of Metrosideros in Hawaii, M. polymorpha (Percy and others, 2008).

Ohia is a remarkable generalist, with the ability to dominate a broad range of sites in Hawaii-from sea level to up to $2,500 \mathrm{~m}$ elevation, and from very wet (up to over $6,000 \mathrm{~mm} / \mathrm{yr}$ ) to dry (about $500 \mathrm{~mm} / \mathrm{yr}$ ) sites. It ranges from status as a colonizing species on Big Island lava flows to dominance on 4 million year old soils on Kauai. It has been evolving in place for a long time and has adapted genetically to local environments, but specialization is limited by within-species gene flow (Vitousek, 2004).

Ohia thus provides the matrix for Hawaii's terrestrial ecosystems and the rich remains of the native fauna and flora, 90 percent of which is endemic, occurring nowhere else in the world. Although perhaps 10 percent of the plant species of the archipelago have been lost to extinction and 30 percent more are endangered, extensive and relatively intact tracts of native-dominated communities survive, mostly at higher elevations. Hawaii has lost roughly half of its original native forest, but 400,000 hectares of ohia-dominated forest remains as of 2009. Ohia forest typically consists of at least 80 percent ohia trees. Most of Hawaii's existing forest is ohia-dominated forest.

Forests dominated by ohia are home to at least 22 extant species of forest birds, the Hawaiian hoary bat, and many of Hawaii's remaining native plants and invertebrates. Endemic Hawaiian honeycreepers, including 16 on the endangered species list, are dependent on these forests for essential habitat, as they have adapted to feed and nest in ohia trees (Buermeyer and others, 2008).

A recent study by Gruner (2004) illustrates that ohia forest still harbors rich arthropod biodiversity that merits protection. Gruner collected arthropods (through canopy fogging with pyrethrins) from Metrosideros polymorpha canopies at 11 sites on Hawaii (9 sites), Molokai (one site), and Kauai (one site) during 1996-2001. Gruner collected more than 50,000 individual arthropods from at least 23 orders, approximately 130 families, and 711 species in 280 genera were recovered from Metrosideros polymorpha at the 11 sites. Of the 711 species listed, there were 497 native taxa (495 endemic, 2 indigenous), 118 adventive, 11 intentionally introduced, and 85 of undetermined origin; the majority of insect species found in these ohia forest sites are endemic.

Not surprisingly for a single species with a very broad ecological distribution, ohia has been shown to have substantial genetic variability (Aradhya and others, 1993; James and others, 2004; Crawford and others, 2008; Percy and others, 2008), as well as phenotypic plasticity (Cordell and others, 1998; Cornwell and others, 2007). [Phenotypic plasticity refers to the important phenomenon involving single genotypes that can produce different phenotypes in different environments (Sultan, 2000).] Ohia is likely well adapted to the large variability in year to year climatic parameters, especially rainfall, so characteristic of Hawaii (for example, Lyons, 1982; Loope and Giambelluca, 1998, p. 506). Although there are, of course, ecological limits to plant phenotypic plasticity (Valladares and others, 2007), and ohia illustrates that fact well through its dieback during certain types of stress (for example, Mueller-Dombois, 1985, Hodges and others, 1986), the phenotypic plasticity of ohia could prove to be important for enabling a certain amount of ecosystem stability in the face of global climate change. The fate of this single foundation (dominant) tree species in relation to climate change is likely to be crucial for the survival of much associated biological diversity at high elevations in Hawaii. 


\section{Threat to Hawaiian Forests}

P. psidii has been found statewide in Hawaii attacking Myrtaceae from near sea level to an elevation of about 1,200 $\mathrm{m}$ in areas with rainfall ranging from $750-5,000 \mathrm{~mm}$ (Robert Anderson, written commun., 2009; J.B. Friday, written commun., 2009). Five native and at least 15 nonnative species have been observed as hosts of $P$. psidii in Hawaii, with the introduced and invasive rose apple (Syzygium jambos) being the most severely affected. Damage to rose apple has occurred at a landscape scale with widespread crown dieback. In spite of billions of wind-dispersed rust spores produced from rose apple infestations, adjacent ohia have been little affected to date by the rust strain in Hawaii. Within the elevation range of the rust in the wild, P. psidii is found on less than 5 percent of the ohia trees; of those ohia trees on which the rust is found, it is normally found on less than 5 percent of the leaves (Robert Anderson, oral commun., 2009).

Because ohia is the dominant tree in most of Hawaii's forests, a continuing outbreak on ohia, similar to that observed on rose apple, could result in significant changes to the structure, composition, and the function of forests on a landscape level. Many (one-third to one-half) of Hawaii's approximately 300 endangered plant species also depend on critical habitat in Metrosideros polymorpha forest. P. psidii is most damaging to young, developing tissue. Although "evergreen," individual leaves of ohia trees are retained for 1.5-2.5 years (Cordell and others, 2001) and require continual replacement. Destruction of new ohia growth would cause not only crown dieback but likely result in low reproduction (few mature flower buds, young fruit). Ohia seedlings would also be severely damaged, further reducing reproduction. Eventually, repeated, severe crown dieback could result in the death of trees as food reserves are used up and no new photosynthetic tissue is added. Increased light reaching the forest floor following canopy dieback would increase the likelihood of invasion by light-loving nonnative species, such as Miconia calvescens, Psidium cattleianum, and introduced grasses. Increases of certain nonnative plants have been shown to cause changes in ecosystem function, for example nitrogen cycling (Hughes and Denslow, 2005). Watershed impacts are also possible with a rapid loss of overstory.

\section{Threat to Hawaiian Culture}

The dominant tree in the Hawaiian Islands, ohia is a species of major cultural significance to the Hawaiian people. Many native plants and animals that depend on ohia forests have cultural significance, but ohia stands out as having special symbolic and spiritual significance because of its connection to the deities $\mathrm{Ku}$, Pele and Laka, as well as obvious material significance. For example, as the native plant symbol of Laka, the deity of hula, ohia is central to a large number of chants and dances, and its loss would affect the spiritual significance of hula and chant (Samuel Gon III, written commun., 2006).

\section{Threat to Hawaiian Fauna, Including Hawaiian Honeycreepers}

Ohia is a major component of montane and lowland wet, mesic and dry forests that are home to one native mammal (Hawaiian hoary bat) and 30 species of forest birds (Hawaii Department of Land and Natural Resources, 2005). A spectacular land bird assemblage, the Hawaiian honeycreepers, an endemic subfamily (Fringillidae: Drepanidinae), evolved in the Hawaiian Islands (Pratt, 2009). Although more than 65 percent of the species are extinct, the remaining species still provide an impressive example of adaptive radiation among birds. Eighteen of 19 extant Hawaiian honeycreepers in the main Hawaiian islands, including 12 of 13 species listed as endangered by the U.S. Fish and Wildlife Service, depend on ohia for critical habitat. Most surviving honeycreeper species inhabit ohia or ohia/koa forests. The continuing decline of honeycreepers and other Hawaiian birds is believed to be largely a result of habitat loss, susceptibility to introduced bird diseases, predation by introduced mammals, competition from introduced birds, and reduction in abundance of arthropod food items (Pratt and others, 2009). Significant degradation of Hawaii's ohia forest by $P$. psidii would negatively affect opportunities for survival of endangered honeycreepers as well as populations of some nonendangered species (anianiau, Kauai creeper, Maui creeper, and iiwi), making them more likely to become endangered.

Many endemic Hawaiian invertebrates also are dependent upon ohia or ohia/koa forests. More than 90 percent of the more than 5,000 known terrestrial invertebrate species are endemic. These species are important as bird food and pollinators of both native and introduced plants. The primary threat to invertebrates is the loss of habitat (Hawaii Department of Land and Natural Resources, 2005). The loss of ohia would have significant negative repercussions on Hawaiian invertebrates.

\section{Threat to Nioi, Eugenia koolauensis, a Federally Endangered Plant Species}

Eugenia koolauensis O. Deg. (nioi), a small tree in the Myrtaceae, was endemic to Oahu and Molokai, but is now found only on Oahu. It is closely related to the indigenous Eugenia reinwardtiana, uncommon on Oahu but a widespread species on Pacific islands. Populations of Eugenia koolauensis were severely depleted by habitat destruction and feral animals, and the species was listed as Endangered by U.S. Fish and Wildlife Service (FWS) in 1994, at which time the number of surviving individuals was estimated at fewer than 60. The species occurs primarily in dry to mesic forests of Oahu's Koolau Mountains, with a few individuals occurring in the nearby Waianae Mountains. Recovery efforts have involved fencing of nioi populations, feral pig removal, and invasive plant removal. The total number of wild individuals had reached more than 2,000 plants in 13 populations by 2007 , 
but infection by $P$. psidii, beginning in 2005, has set recovery back substantially (Zablan, 2007).

Reduction in rust spore dispersal for nioi was reduced after 2008, by which time new leafing of rose apple trees had been depleted by at least 3 years of continual heavy infection by $P$. psidii. Investigations are needed to clarify rust-nioi relationships. However, it is likely that keeping out new strains of P. psidii may be important for long-term nioi survival.

\section{A Note on Terminology Below the Species Level}

International Phytosanitary Measure (ISPM) No. 5 (International Plant Protection Convention, IPPC Secretariat, 2008) and ISPM No.11 (IPPC Secretariat, 2004) were referred to for guidance regarding what terminology below the subspecies level (such as strain, race, biotype, pathotype, genotype, genotypic, and spectrum) might be preferred by the international phytosanitary system.

ISPM No. 11 states in Section 2.1.1.1:

The taxonomic unit for the pest is generally species. The use of a higher or lower taxonomic level should be supported by scientifically sound rationale. In the case of levels below the species, this should include evidence demonstrating that factors such as differences in virulence, host range or vector relationships are significant enough to affect phytosanitary status. (IPPC Secretariat, 2004, p. 122)

Because ISPM No. 5, Glossary of Phytosanitary Terms, includes none of the above subspecific terms, an authoritative review article by Bos and Parlevliet (1995) was used as a model. They stated:

Parasite-specific resistance induced by breeding is often overcome by mutation and genetic adaptation of the parasite. The genotype of the parasite that neutralizes the resistance is indicated as a new biotype, race, pathotype, or strain ...

They review definitions of these and other terms, as given by various authorities.

The term forma specialis is defined as a "subdivision of a species of a parasitic or symbiotic microorganism distinguished primarily by adaptation to a particular host." Biotypes are "merely biological variants."

Consensus exists on use of the term "physiological race" (= "race") for a group "of parasites (particularly fungi) characterized by specialization to certain cultivars of one host species."

Bos and Parlevliet (1995) state that the term pathotype has been defined as "a subdivision of a species, distinguished by common characters of pathogenicity, particularly in host range," then merging with physiologic race. They agree with an authority who has suggested that "pathotype should be used only in relation to gene-for-gene interactions." They go on to state: "The wider term strain denotes all sorts of characterized and thus recognizable variants," including physiological race.

Usage by Bos and Parlevliet (1995) and (or) usage by specific cited references have guided the terminology used for P. psidii and other rust pathogens below the species level.

\section{Genetic Variation}

\section{Potential Impacts of Different Strains on Host Parasite Interactions}

Rust fungi such as Puccinia spp. are often used as the classic example of the gene for gene interactions that can result in the expression of resistance and susceptibility in plant hosts. Like a key in a lock, virulence genes in the pathogen must overcome host genes (Agrios, 2005). Host resistance genes can be major, dominant genes conferring "vertical resistance," or multiple loci conferring "horizontal" or "quantitative" resistance. Horizontal resistance may be less complete, but is usually more stable, in that multiple loci of virulence genes would be required to overcome quantitative resistance. The existence of resistance and virulence genes in host and pathogen are the result of evolutionary development of obligate parasites, such as the rust fungi (Deadman, 2006). Thus within the original distribution of a pathogen, resistance genes in host plant populations could well mask the potential for destruction that may be present in the many genotypes of the pathogen that might exist. Any resistance in host plants outside the native range of the pathogen is likely due to nonspecific reactions to infection rather than gene for gene interactions, which may or may not be effective against other strains of the pathogen. It is notable that a substantial amount is known about the genetic basis for resistance to P. psidii in Eucalyptus grandis, a species that has long evolved far outside the native range of the rust (see Moon and others, 2007); however, the implications of this circumstance are not entirely clear.

\section{Known Genetic Variation in $P$. psidii}

Almost nothing is known about the genetics of $P$. psidii worldwide at a level that would be pertinent to host specificity. This may not be surprising as there has apparently not been much interest in refining knowledge of races or strains. To date, the greatest interest may have been by biocontrol researchers interested in using $P$. psidii as an adjunct organism (already present) for biocontrol of Melaleuca quinquenerrvia, an invasive tree (in the Myrtaceae) in southern Florida (Rayachhetry and others, 2001).

In response to interest in the topic in Hawaii, Zhong and others (2008) developed and characterized 15 polymorphic microsatellite markers present in the genome of Puccinia psidii. The primers for these microsatellite markers were designed by sequencing clones from a genomic DNA library 
enriched for a simple sequence repeat (SSR) motif of (AG). All these 15 primer pairs successfully amplified DNA fragments from a sample of 22 P. psidii isolates, revealing a total of 71 alleles. The observed heterozygosity at the 15 loci ranged from 0.05 to 1.00 . Zhong (oral commun., 2007) has used the simple sequence repeat (SSR) markers developed to examine variation in a small $P$. psidii sample (4 samples from Florida, 12 from Brazil, and 12 from Hawaii). Results suggested little or no variation in the Hawaii samples and more in samples from Florida and Brazil.

Research funded by the U.S. Forest Service and others is underway in Brazil to determine relationships between genetics and aggressiveness of $P$. psidii against ohia (Cannon and others, 2009). This work appears to have much potential for expanding knowledge of genetic variation within P. psidii, but results may not be available for several years.

\section{A Molecular Diagnostic Test for $\boldsymbol{P}$. psidii}

Langrell and others (2008, p. 687) have recently developed what shows much promise as an effective and flexible diagnostic test for $P$. psidii at the species level:

A species-specific, nested polymerase chain reaction (PCR)-based detection assay, using two primer sets designed from the rRNA ITS region, was developed for Puccinia psidii. Detection sensitivities of one urediniospore alone, or one or two urediniospores in the presence of pollen or leaf tissues, respectively, were observed. The assay reliably, accurately and sensitively detected the rust from naturally infected, geographically widespread eucalypt and fruit tree plantation and nursery species from diverse tissue types (e.g. leaves, flowers, fruits, pollen, seeds and woody material) including symptomless or cryptically contaminated plants or plant tissue. Independent testing in Brazil and Australia demonstrated the international inter-laboratory transferability of the P. psidii assay required for germplasm screening, disease monitoring and quarantine and incursion management, towards which the assay has already been employed.

It might well be feasible to use the molecular diagnostic test of Langrell and others (2008) for testing germ plasm (seeds or tissue culture) of Eucalyptus, Myrtus, Chamaelaucium or any genus of Myrtaceae brought into Hawaii under permit for the purpose of establishing additional breeding stock. For many reasons, it seems unlikely that it would be desirable or practical for Hawaii to test for P. psidii at a more discriminating level (below the species level) than the test of Langrell and others (2008) (see next section). The technology probably exists to do discriminating analysis at the level of the gene, but it seems to have been done only for relatively few model species of plants, probably not for pathogens and almost certainly not for rusts. One plant crop example involves development of PCR-based single-nucleotide polymorphism (SNP) markers for rice blast resistance genes (Hayashi and others, 2004).

\section{Indirect Evidence of the Existence and Consequences of Genetic Variation in P. psidii}

Almost nothing is known directly about the genetics (and presumed races) of $P$. psidii; however, abundant literature exists for races of related rust fungi, most notably for two of the Puccinia species notorious for diseases of wheat, one of the world's major food crops. The two species are Puccinia graminis (the so-called stem rust pathogen of wheat and other small grains) and $P$. striiformis (stripe rust of wheat and related species). Not surprisingly, there is a large knowledge base about these important Puccinia rust species. Such knowledge is instructive for understanding the likely genetic situation in $P$. psidii. For example, Broeker and others (2006b) rationalize the significance of their work on gene expression with the statement: "Puccinia graminis was used as a model organism for the rust fungi which are not well investigated on the molecular level today." Furthermore, P. graminis is one of the relatively few rust fungi that can be practically grown in axenic culture (in vitro, on a nonliving substrate), so that it can uniquely be examined in pure culture apart from its host organism and used to identify critical pathogenicity factors or genes involved in crucial developmental stages (Broeker and others, 2006a). Rust fungi are notoriously difficult organisms to study; more than 100 years of research has resulted in detailed knowledge of relatively few species, and there is much yet to learn about even the most studied ones (Staples, 2000). Staples (2000) stated in his review of rust research during the 20th century that the overall effort has been driven by the desire to produce rust-resistant plants. That observation is consistent with the history of work on P. psidii, for which the culminating publication to date is that of Moon and others (2007) on molecular details of resistance, although the sophisticated work of Langrell and others (2008) confirms a very high level of border quarantine concern in Australia, presumably to protect native forests which are dominated by Myrtaceae.

Since 2000, at least 67 races or pathotypes Puccinia striiformis f. sp. tritici have been identified on wheat in China and 109 in the United States and Canada (Chen, 2005).

Would comparable strains or races exist in P. psidii if similar research were to be focused on it as on the wheat rusts? One can state with some confidence that many genotypes of $P$. psidii would likely have differences in susceptible host spectrum at some location (such as Hawaii), given the substantial variation of host range in "biotypes" already known from the limited studies completed to date, as summarized by Glen and others (2007) and others. P. psidii currently has only one race in Hawaii, at least several races in Florida, and probably many others elsewhere. Conservatively, three to four races were recognized in each of several locations through the differential susceptibility of hosts (discussed above); see Coutinho and others (1998), Xavier (2002), and Aparecido and others (2003). 
It should be noted that Junghans and others (2003) reported finding a "disease resistance gene" ("although clearly incomplete penetrance, variable expressivity and minor genes are also involved") that confers resistance against $P$. psidii in Eucalyptus grandis. (The gene was originally present in only a small percentage of the E. grandis trees of Brazil plantations but was found in a few resistant individuals, which could then be cloned.) This was quite a remarkable finding - one of the few documented examples of the involvement of a major resistance gene in a noncoevolved pathosystem. Their explanation of the scientific significance of their find is enlightening:

Plant-pathogen interactions conferring resistance through single genes are usually interpreted as a gene-for-gene relationship (Flor, 1971). Such a type of relationship usually results from co-evolution of the pathogen and the host, resulting in a high degree of specialization in the majority of pathogens. This premise, however, does not appear to be valid in the P. psidii-Eucalyptus pathosystem. Eucalyptus originated in Australia and neighboring islands. It was introduced into Brazil for commercial purposes by the end of the 19th century. P. psidii, on the other hand, is native to South America and attacks various species of native or exotic Myrtaceae. Up to now, this pathogen has not been found in Australia where Eucalyptus grows naturally (Coutinho and others, 1998).

The major resistance gene identified in the P. psidiiEucalyptus pathosystem is similar to monogenic resistance genes found in Pinus and Populus that did not coevolve with the pathogen. The resistance in these cases can be conferred by genes of resistance to similar pathogens found in the centers of origin of the host. The resistance to C. ribicola identified in P. lambertiana (Devey and others, 1995) appears to be the first case of a non-co-evolved pathosystem expressing monogenic resistance. At the same time there is a history of co-evolution between the genus Pinus and the genus Cronartium that goes back to their ancestors in the northern part of Central Asia (Leppik, 1970). This is not the case with the Eucalyptus- $P$. psidii pathosystem. A plausible explanation in this case is that gene Pprl confers resistance to other pathogens in the center of origin. Recent studies indicated that the same gene could confer resistance to different species of organisms, as the Mi gene in tomato conferring resistance to [the nematode] Meloidogyne incognita and aphids (Rossi and others, 1998).

The work of Moon and others (2007) built on that of Junghans and others (2003), looking closely at what is involved with the contrasting genetically based responses to infection of a $P$. psidii-resistant versus a susceptible strain of Eucalyptus grandis in Brazil. This work indicates that very complex genetic interactions are involved, as indicated by enzymes activated in the resistant strain versus the susceptible strain (Moon and others 2007, p. 1010):

Eucalyptus grandis Hill ex Maiden and its hybrids are commonly planted by the Brazilian pulp and paper industry, but they are the most susceptible to the neotropical rust disease caused by Puccinia psidii Winter. In an initial attempt to understand the mechanisms of resistance, we constructed two contrasting Serial Analysis of Gene Expression (SAGE) libraries using susceptible and resistant individuals from a segregating half-sibling $E$. grandis population. Using the Z-test we identified tags differentially expressed between the libraries, preferentially 239 in the susceptible and 232 in the resistant type individuals. Using public (Expressed Sequence Tags) EST databases, 40 of the susceptible and 70 of the resistant tags matched ESTs and were annotated. By comparing the type of genes and their expression levels, distinct differences between the libraries were observed. Susceptible plants showed gene expression linked to leaf senescence, generalised stress responses and detoxification, and are apparently incapable of inducing a competent host defence response. On the other hand, resistant plants showed genes upregulated for cellular polarisation, cytoskeleton restructuring, vesicle transport, and cellulose and lignin biosynthesis. In the resistant individuals, evidence for systemic resistance, anti-oxidative responses and a hypersensitive response was also observed, although no R gene was identified.

They concluded (p. 1015-1016):

From the number and type of upregulated genes in the resistant plants, it seems that two responses are occurring and contributing to the resistant phenotype. First, cellular polarisation, which involves massive rearrangement of the cytoskeleton, translocation of cytoplasm and the cell nucleus to the fungal penetration site, and local reinforcement of cell wall by successive deposition of layers of wall material (Schmelzer, 2002). Second, a group of specific anti-pathogen mechanisms including systemic resistance, hypersensitive and oxidative responses that together lead to resistance...

This current work indicates that several mechanisms of host defence/resistance are active in the Eucalyptus-Puccinia pathosystem, such as cellular polarisation and a putative hypersensitive response, contributing to generate the resistant phenotype. This is, however, not contradictory to the work of Junghans and others (2003) that indicates the presence of a major resistance gene. This gene could be any of the above-mentioned genes that is preferentially expressed when the resistant plant is exposed to the 
pathogen, for example the type I chitinase. Besides this, it was interesting to note that in the 20 most expressed tags from each library, eight in susceptible and six in the resistant, represented genes with unknown functions potentially involved in the host response to the pathogen. Therefore, further work is necessary to confirm the role of these resistance genes in this Eucalyptus-Puccinia pathosystem and indicate molecular markers for future markerassisted eucalypt breeding programs.

There is a growing literature regarding how even a single amino acid sequence difference in a crop plant's genome can make the difference between susceptibility or resistance to a serious disease (for example, Warren and others, 1998; Bryan and others, 2000). A reasonable conclusion may be that one simple gene mutation (a change of one base pair) in $P$. psidii has potential for producing a new race or strain, that can be defined by how it changes its ability to utilize (as a host) one or more species of Myrtaceae in a given area. Such changes will be more likely if variation is introduced into the pathogen population, resulting from either sexual or somatic recombination.

\section{Direct Evidence from the Literature that Multiple Strains or Races of $\boldsymbol{P}$. psidii Exist}

Coutinho and others (1998) raised the issue of multiple "races" and predicted serious consequences from spread of $P$. psidii to areas where the rust would come into contact with the genus Eucalyptus in its native habitat and other evolutionarily unexposed species. They also presented the species, P. psidii, as the most serious threat to eucalypt plantations worldwide and provided an early warning 10 years ago in their publication Eucalyptus rust: a disease with the potential for serious international implications. They touched upon the existence of "a race or races" but their review of the literature suggested many enigmas and gaps in knowledge for this pathogen:

International Importance

P. psidii is an unusual rust in that it has an extremely wide host range amongst genera and species of Myrtaceae. Its occurrence on Eucalyptus spp. appears to be one of the unexpected and unfortunate consequences of exposing the rust to this host in a non-native situation. The occurrence of $P$. psidii on Callistemon speciosus, another Australian myrtaceous plant, in South America, is an example of the same phenomenon. At this stage it would appear that a race or races of the rust are well established on Eucalyptus spp. The potential for these fungi to result in epidemic disease situations in the areas of origin of Eucalyptus spp., and perhaps other myrtaceous genera, seems real, and could be a serious threat to global biodiversity. Such a situation would be equivalent to other introduced epidemic tree diseases, such as Dutch elm disease (caused by
Ophiostoma ulmi (Buisman) Nannf. and O. novoulmi Brasier), chestnut blight (caused by Cryphonectria parasitica Murrill (Barr), pine wilt (caused by Bursaphelenchus xylophilus Steiner \& Buhrer), and white pine blister rust (caused by Cronartium ribicola J.C. Fisch). (Coutinho and others, 1998, p. 824)

After P. psidii made the long jump to Hawaii in 2005, several articles appeared in 2006-7 reviewing its threat to Australia and other non-neotropical locations. An excerpt from one of them, Glen and others (2007), provides as good an overview as exists to date of current understanding relevant to the concept of "strains" of $P$. psidii (strains or races are generally recognized through their ability or inability to infect different hosts):

\section{Host range and biotypes}

The host range of $P$. psidii has been studied in Florida, with a view to using $P$. psidii as a biocontrol agent for the Australian native tree Melaleuca quinquenervia, which has become an invasive weed in the Everglades (Rayachhetry and others, 2001). Of the 14 exotic and four native species of Myrtaceae tested with two collections of $P$. psidii urediniospores, 10 were asymptomatic or had symptoms without sporulation. These included $E$. grandis and $S$. jambos, which were both susceptible in other laboratory tests and in the field (Marlatt and Kimbrough, 1979). The endangered native Myrcianthes fragrans was susceptible, but the authors suggested that the host range may have been artificially expanded by the controlled environment tests. This was because Callistemon viminalis and Syzygium cumini, which also tested positive in their experiments, were observed growing in close proximity to infected M. quinquenervia with no evidence of infection. However, natural infections of C. viminalis, M. fragrans and S. cumini, as well as C. citrinus, Myrtus communis, S. paniculata and S. jambos were subsequently reported in 2002 and 2003 (Leahy, 2004). It is possible that the presence of susceptible new growth on these species had not previously coincided with the high inoculum load and environmental conditions conducive to infection.

Susceptibility of different provenances of selected Australian Myrtaceae species to P. psidii was tested in Brazil as part of a project funded by the Australian Centre for International Agricultural Research (ACIAR) (FST/1996/206) between CSIRO Forestry and Forest Products, Australia, Forestry and Agricultural Biotechnology Institute, South Africa, and the Federal University of Vicosa, Brazil. Of the 58 Australian species tested, 52 had some degree of susceptibility (A.C. Alfenas and E.A.V. Zauza, unpubl. data) and, for most species, the degree of 
susceptibility varied among provenances. Thirtynine of the species tested were species of Eucalyptus or Corymbia, and 37 of these were susceptible.

Artificial inoculations in the ACIAR tests in Brazil extended the host range beyond the Myrtaceae when the South African species included in the study showed that Heteropyxis natalensis was highly susceptible (Alfenas and others, 2005). This tree genus belongs to the Myrtales but is classified as Heteropyxidaceae. This is, therefore, the first recorded non-Myrtaceae host of P. psidii. [Note: Heteropyxis was transferred to the Myrtaceae, based on molecular evidence (Wilson and others, 2005).]

Several races or biotypes of $P$. psidii are known to exist; although in comparison with other rusts such as those of cereal crops, very little is known of these specialised forms. For example, two strains in Jamaica infected Pimenta spp. and Syzygium spp., respectively, but neither strain infected guava (MacLachlan, 1938). The Pimenta strain was able to infect $S$. jambos but did not sporulate. In Florida, the Pimenta strain sporulated on S. jambos (Marlatt and Kimbrough, 1979), even though it took twice as long for maturation of urediniosori in $S$. jambos than on $P$. dioica. In later tests, $S$. jambos was considered immune to rust strains from M. quinquenervia and Pimenta dioica (Rayachhetry and others, 2001). [At least two strains.]

In Brazil, isolates from guava did not infect eucalypts and vice versa (Ferreira, 1983). The physiological variability of $P$. psidii was assessed by crossinoculation on E. grandis, P. guajava and S. jambos, with 13 single-pustule isolates from $E$. cloeziana, $E$. grandis, E. phaeotricha, P. guajava, S. jambos and Myrcia itambensis (Coelho and others, 2001). Three groups of physiological specialisation (biotypes) were detected, the first compatible with E. grandis and S. jambos, the second with E. grandis and guava, and the third only with guava. No difference was detected in incubation period and mean latent period among the groups; however, the number of sori per unit area varied among the groups (Coelho and others, 2001). [Three strains.]

In another study, Xavier (2002) evaluated the virulence of 32 isolates of $P$. psidii, obtained from different hosts and regions on five Myrtaceae species (E. grandis, S. jambos, Eugenia jaboticaba, $P$. guajava and E. uniflora). The frequency of isolates virulent on these plants was $100,87,81,31$ and 4 percent, respectively. Virulence testing of 21 of these isolates on eight Eucalyptus clones showed three different interaction responses. The isolates were characterized on the basis of these responses as belonging to race 1, 2 or 3 . Races 1 and 3 were from Eucalyptus and race 2 from guava (Xavier, 2002). [Three races.]

Aparecido and others (2003) performed cross-inoculation experiments using urediniospores of $P$. psidii collected from eight different host species: jambo ( $S$. jambos), E. grandis, three other unspecified Eucalyptus species, guava (P. guajava), jaboticaba (Myrciaria cauliflora) and cambuca (Eugenia cambucae). These were inoculated onto five different host species: Corymbia citriodora, guava, jambo, cerejaderio-grande (Eugenia sp.) and uvaia (E. uvalha); and four different groups (biotypes) were discriminated on the basis of host specificities. The relationship between the biotype from all-spice in Jamaica and Florida and those from Brazil is unknown.

[Four races.] (Glen and others, 2007, p .6-7)

In summary, there is clear evidence that physiological races or strains of $P$. psidii exist, but there has been as yet no effort to formally establish and test for them over defined areas. This situation is consistent with Wingfield's (2003) observations that funding for taxonomic and ecological studies of fungal plant pathogens, even of ones with obviously serious future consequences for forestry trees and for biodiversity concerns, "is hopelessly inadequate." The driving forces behind funding internationally have primarily been (1) to address the problem of economic loss from P. psidii in Eucalyptus stands in Brazil and (2) to address the perceived need in Australia for a diagnostic test for $P$. psidii as a tool in border protection quarantine. Systematic delineation of strains has not been considered important for either of those efforts.

\section{Evidence that Hawaii's "Strain" of $P$. psidii is Different from Other Populations-Baseline Characterization of the Host Range of $P$. psidii in Hawaii, 2005-2008}

Simpson and others (2006) compiled a list of known host species of $P$. psidii and noted a generally greater vulnerability of nonneotropical Myrtaceae to the rust:

Guava rust, Puccinia psidii, is now known to occur on species in both subfamilies of Myrtaceae, including one of two tribes of the subfamily Psiloxyloideae and seven of the 15 tribes of subfamily Myrtoideae, a total of 20 genera and 71 species. Susceptibility to Puccinia psidii seems to be low among species of Myrtaceae from the Americas but more common among taxa from Asia, Australia and the Pacific.

Within myrtaceous genera known to be host to one or more rust species usually only a small proportion of the species is known to be susceptible... 
furthermore within susceptible species there is often wide variation in susceptibility between plants and provenances, and in susceptibility to different races of P. psidii (MacLachlan, 1938; Junghans and others, 2003; Tommerup and others, 2003). Despite extensive collecting of species of Uredinales in northern South America and Central America for more than 120 years (Figueiredo and Hennen, 1998), P. psidii is known from only 10 genera and 28 species of native hosts, out of more than a thousand potential hosts ... . The limited host range in the Americas suggests $P$. psidii has exerted strong selection pressure on the native Myrtaceae for many generations. Epiphytotics in indigenous species have been reported only for a few genera including Psidium (Andrade, 1951; Junqueira and others, 2001) and Pimenta (MacLachlan, 1936; 1938) both of which are cultivated as monocultures.

The Hawaii P. psidii population is likely clonal, without genetic variation. It may differ most notably from populations elsewhere in its failure to significantly infect nonnative common guava Psidium guajava and allspice Pimenta dioica (Uchida and Loope, 2009). [Note: A single susceptible population of allspice has recently been reported by researchers in Oahu's Waianae Mountains. Genetic analysis of the P. psidii suggests no difference from other populations. (Janice Uchida, oral commun., 2009)] Nonnative Eucalyptus spp. present in Hawaii (about 100 species), mostly large trees planted decades ago, have been largely unaffected. In Brazil, Eucalyptus spp. are characteristically infested only when younger than 4 years old. The dramatic effect on rose apple Syzygium jambos is also noteworthy, and its explosive infection by spores of $P$. psidii has been characterized as a recurrent epiphytotic (Uchida and Loope, 2009):

A Neotropical rust of the Myrtaceae, Puccinia psidii Winter, was described from Psidium guajava L., or guava, in Brazil in 1884 [Coutinho and others, 1998]. It was first discovered in Hawaii on potted Metrosideros polymorpha Gaud. on Oahu in April 2005 [Killgore and Heu, 2005] with pathogenicity and identity established [Uchida and others, 2006]. It spread quickly, and by January 2006, severe outbreaks of this rust occurred statewide on new leaves of Syzygium jambos (L.) Alston, or rose apple.

Rose apple, a native to South and Southeast Asia, was introduced to Hawaii in 1825 and is locally abundant to invasive from just above sea level to as high as $1,000 \mathrm{~m}$ in elevation in wet sites. Healthy, reddish green immature leaves on new twigs become deformed, yellow-red, and covered with masses of yellow urediniospores following infection. As the disease progresses, infected leaves are blackened and defoliate, with no functional leaves formed. Stem tips and branches are killed and the canopy becomes progressively smaller. Repeated mortality of juvenile leaves was observed to kill 8 to $12 \mathrm{~m}$ tall trees in the Haiku area of Maui. Wind dispersal of spores resulted in heavy infection of even small groups of $S$. jambos isolated by $1 \mathrm{~km}$ or more and billions of spores covered the ground under diseased trees. On Hawaii, Maui, and Oahu, trees with many dead branches are becoming common with concerns about the fire hazard of these dead trees surrounded by dry grasses. At low humidity levels, or on more mature leaves characterized by soft expanded yellow-green tissue, fewer, mostly circular spots are formed that do not expand. S. jambos is an example of a highly vulnerable host in Hawaii and represents one of approximately 3,500 species of Myrtaceae outside the Neotropics growing in Australasia, Southeast Asia, the Pacific, and tropical Africa, which have evolved unexposed to $P$. psidii. Severely infected S. jambos plants have been the major source of spores in the environment, exposing many Myrtaceae hosts to $P$. psidii. The pathogenicity of $P$. psidii has been consistent among and within islands with $S$. jambos severely infected and M. polymorpha, Melaleuca quinquenervia, Rhodomyrtus tomentosa, Myrtus communis, and Eugenia species commonly infected. Other hosts such as $S$. cumini, S. malaccense, and Myrciaria cauliflora are also infected, although guava and Eucalyptus spp. are rarely infected. Strain differences within $P$. psidii are suspected [Zhong and others, 2008]. In the tropics, it is rare for mature trees to be killed by a foliar pathogen, but given the devastation of new growth, death of more $S$. jambos trees is likely.

Rose apple has long been widely cultivated through the tropics and is widely naturalized (Staples and Herbst, 2005), not only in Hawaii but in the neotropics. It is one of the cultivated Myrtaceae host plants most heavily attacked by $P$. psidii in Brazil, where it seems to survive in plantings such as those studied by Tessmann and others (2001) on the campus of University of Brasilia:

Rose apple (Syzygium jambos) . . . is severely damaged by ... Puccinia psidii .... The fungus colonizes young leaves and stems of juvenile flush growth, flowers and young fruits of rose apple. Major epidemic outbreaks occur annually in Brasilia, causing premature defoliation, destructive die-back, and loss of flowers and fruits. In addition, urediniospores produced in rose apple may serve as inoculum for other Myrtaceae, including some economically important species such as Eucalyptus spp. and guava. (Tessmann and others, 2001)

However, in multiple areas of the neotropics with $P$. psidii present, rose apple is a major successional tree on abandoned pastures or cultivated lands; no indication could be found in the literature that $P$. psidii has any impact on it. In 
Puerto Rico, for example, all recent articles on plant succession on abandoned crop field or pastures in Puerto Rico agree that Syzygium jambos is the most important nonnative plant invader, especially at 60 to 80 years after abandonment (Aide and others, 1996; Brown and others, 2006; Marin-Spiotta and others, 2007; and Thompson and others, 2007). It is dominant in some areas. Brown and others (2006, p. 145) state that:

$S$. jambos has ... altered vegetation composition and diversity patterns in habitats where it is the dominant tree species. After nearly 185 years since its introduction to the island, $S$. jambos is not only well established within $30 \mathrm{~m}$ of stream channels, its presence does not appear to be limited by topographic, soil nutrient, or elevational conditions.

Kerry Brown, the senior author of the paper cited above on invasion of old fields in Puerto Rico by rose apple was contacted, and he wasn't familiar with $P$. psidii. On the basis of the literature, it would appear that there have never been outbreaks of this pathogen at a landscape scale in Puerto Rico, although $P$. psidii has been there for at least several decades, suggesting that a different strain is present in Puerto Rico.

A similar situation occurs in the Dominican Republic, where Sherman and others (2005) found rose apple to be a dominant species in "secondary riparian forests" of the Cordillera Central:

These forests occurred along the lower river valleys below $1,300 \mathrm{~m}$ elevation that were cleared prior to the establishment of the national parks. These forests are distinct due to the dominance of two introduced species: Inga vera Willd., a species native to the island but not the mountains, and Syzygium jambos (L.) Alston, a non-native species.

Syzygium jambos (poma rosa) is also considered invasive in Cuba (Borhidi, 1996). In Costa Rica, S. jambos is the dominant tree species in a remnant patch of forest of Ciudad Colon, near San Jose (Di Stefano and others, 1998). In Panama, it is naturalized along streambeds and is used for fruit and firewood with seven other nonnative plant species among 119 noncultivated species used by the local community of the Las Pavas region (Aguilar and Condit, 2001).

Not surprisingly, some previously unrecorded Myrtaceae host species have been recorded for the rust in Hawaii. The relatively definitive list by Simpson and others (2006) has already included Metrosideros polymorpha and Eugenia koolauensis based on the report of Killgore and Heu (2005). Another native (indigenous) species of Hawaii, Eugenia reinwardtiana, was included in the list of Simpson and others (2006) because it had previously been reported from Florida. Eugenia reinwardtiana and the federally endangered E. koolauensis are very seriously damaged by the rust. Host species for addition to a comprehensive list would include the following species from Hawaii:

- Chamelaucium uncinatum Schauer, Geraldton waxflower; endemic to Western Australia, cultivated in many places in the world, including California and Maui, Hawaii. Geraldton waxflower is in the Chamelauciae, now the 8th tribe of Myrtoideae documented as susceptible to infection by $P$. psidii. Damage is sufficiently severe to have resulted in substantial decline of some of the cultivated plants of C. uncinatum in Kula, Maui. (L. Loope, unpub. data.)

- Metrosideros collina (J.R. Forst. and G. Forst.) A. Gray; present (from Vanuatu) in National Tropical Botanical Garden (NTBG), a host for the rust. (Robert Anderson, written commun., 2009.)

- Metrosideros excelsa J. Gaertner, pohutukawa, a New Zealand species; a few individuals seriously damaged by $P$. psidii in Lyon Arboretum. (Robert Anderson and Robert Hauff, written commun., 2009.)

- Metrosideros kermadecensis W.R.B. Oliver; several individuals in Lyon Arboretum serving as a host for the rust. (Robert Anderson, written commun., 2006-9.)

- Monimiastrum globosum J. Gueho and A.J. Scott = Eugenia kanakana N. Snow; endemic to Mauritius (Snow 2008); one specimen in National Tropical Botanical Garden, Kauai, very seriously damaged by the rust. (Robert Anderson and David Lorence, written commun., 2009.)

- Rhodomyrtus tomentosa (W. Aiton) Hasskarl; an invasive plant on several Hawaiian islands, very significantly affected by the rust on Kauai (J.B. Friday and Robert Anderson), designated a noxious weed by HDOA. Although populations of this species on Kauai are hit hard by $P$. psidii, those on Oahu are damaged much less and those on the island of Hawaii not at all (Robert Hauff and Robert Anderson, written commun., 2006-9). Although Rhodomyrtus tomentosa is invasive in South Florida, especially in Collier County, it has apparently not yet been reported as a host of P. psidii in Florida.

- Syzygium sandwicense Gray, an endemic species in Hawaii; minor damage by $P$. psidii on plants on Kauai and Oahu, observed by Robert Anderson (written commun., 2009).

Five species of Metrosideros (M. polymorpha, $M$. macropus, $M$. rugosa, $M$. tremuloides, and $M$. waialeale) and five varieties of Metrosideros polymorpha (vars glaberrima, incana, macrophylla, newellii, and polymorpha) were recognized in Hawaii by Dawson and Stemmerman (1999). However, James and others (2004) found that "the high degree of overlap between the taxonomic varieties, based on genetic and morphological characteristics, does not support the current varietal subdivision of Metrosideros polymorpha on Hawaii." Percy and others (2008) stated further that "the chloroplast [genetic] data do not support the recognition of five distinct 
species in the Hawaiian Islands." If one accepts the verdict of Percy and others (2008) that all Hawaiian Metrosideros is best recognized as a single, highly variable species, all four species of native Myrtaceae (three endemic, one indigenous) in Hawaii have demonstrated vulnerability, ranging from minor to severe, as hosts for Hawaii's strain (a single genotype?) of P. psidii. On the other hand, if one accepts the traditional treatment by Dawson and Stemmerman (1999) that there are five species of Hawaiian Metrosideros, two of the five (M. polymorpha and M. tremuloides) have been documented as hosts of $P$. psidii in Hawaii, making a total of five of eight native species infected (four endemic, one indigenous).

In addition to the hosts listed above and by Uchida and Loope (2009), the following are significant hosts in Hawaii:

- Eugenia uniflora L., Surinam cherry (Eloise Killgore, written commun., 2009), native to the neotropics, where it has been recorded as a host of $P$. psidii.

- Syzygium paniculatum J. Gaertner, bush cherry, an Australian species. Damage to this species in Hawaii by $P$. psidii is locally severe, particularly in the area of Waimea on the island of Hawaii (J.B. Friday, written commun., 2009) . In contrast, Ploetz and others (2008) point out that bush cherry has been unaffected by $P$. psidii in South Florida nurseries, although it has been recorded as a host of $P$. psidii in Florida.

\section{Sexual Recombination or Lack Thereof in Puccinia psidii}

There is some disagreement about the likely life cycle of P. psidii within its native range. Simpson and others (2006, p. 555) stated:

Puccinia psidii is presently considered to be a hemicyclic, autoecious species (Gaumann 1959; Coutinho and others, 1998). Neither spermogonia nor aecia have been observed in field collections (Hennen and others, 2005). Figueiredo and others (1984) reported that aecia and aeciospores were produced following inoculation of leaves of S. jambos with basidiospores. The aecia and aeciospores were morphologically indistinguishable from uredinia and urediniospores i.e. P. psidii forms aecial uredinia and aecial urediniospores. Presence of aecial urediniospores was also reported by Ferreira (1989) on Eucalyptus. It is possible that $P$. psidii is apomictic and the first spores produced from basidiospore infections are already urediniospores.

Abundant formation of teliospores and basidiospores (Ruiz and others, 1989) indicates to us that P. psidii is a heteroecious macrocyclic rust with an undetermined alternate aecial host. Hennen and others (2005) list 67 species of Aecidium (Pers.) Pers. and three species of Endophyllum J.H. Léveille from Brasil. The aecial state of P. psidii may be one of these taxa.

Glen and others (2007, p. 2) later stated:

Puccinia psidii is considered to be an autoecious species with an incomplete life cycle (Fig. 3). With the exception of spermogonia, all stages are produced on the same Myrtaceous host. Aecia and aeciospores are morphologically identical to uredinia and urediniospores (Figueiredo 2001; A.C. Alfenas and E.A.V. Zauza, unpubl. data). It has recently been suggested that $P$. psidii may be heteroecious with an unknown aecial host (Simpson and others, 2006) but this seems doubtful given the multiple observations, in independent laboratories, of infections on uredinial hosts (E. grandis and S. jambos) inoculated with teliospores or basidiospores (Figuiredo, 2001; A.C. Alfenas and E.A.V. Zauza, unpubl. data).

Although these two interpretations differ substantially, each is probably compatible with the likelihood that $P$. psidii sometimes reproduces sexually in part or all of its home range. If it does, there is abundant potential for more rapid evolution. MacLachlan (1938) and Marlatt and Kimbrough (1979) reported finding no spores of $P$. psidii other than asexual urediniospores in field situations in Jamaica and Florida respectively. It is possible that there may be no sexual reproduction outside the native range. That situation is thought to be the case with coffee rust, Hemeleia vastatrix (Rodrigues and others, 1976). However, Janice Uchida (written commun., 2009) has found that in Hawaii, "urediniospores (yellow, single celled with spines) are common but almost equally common are the teliospores (two celled, more orange/brown, and smooth) and basidiospores (small hyaline spores formed from the teliospore, fragile). Thus it is only the aecial stage is that we have not seen."

Staples (2000) states, "Recombination in plant pathogens occurs either through sexual reproduction or through a process of somatic hybridization, in which nuclear and cytoplasmic material may be exchanged. In turn, nuclear exchange may be followed by nuclear fusion and recombination (parasexual cycle). All of these mechanisms may generate increased genotypic diversity in a pathogen population, but their importance varies both within and among species."

Because of their ability to produce billions of asexual urediniospores on susceptible host plants, rusts have potential for evolution without a sexual cycle. Mechanisms and drivers of asexual reproduction have been assessed for wheat stem rust and stripe rust of wheat in Australia. The original introduction of stem rust (Puccinia graminis f. sp. tritici) likely occurred after European settlement in the 1780s. Since that time, sexual recombination has been prevented by the absence of the obligate (for a sexual cycle) alternate host, Berberis spp. As a consequence, the pathogen population has developed as a series 
of clonal lineages that have each expanded from the founding ancestral race to produce more than 100 pathotypes. These pathotypes have a virulence range that reflects the resistancegene deployment strategies used in wheat in Australia over the period (Burdon and Silk, 1997; McIntosh and Brown, 1997).

The original introduction of stripe rust (Puccinia striiformis f.sp. tritici) was first detected in Australia in 1979. More than 20 new pathotypes with assorted virulence characteristics have since been detected in Australia and New Zealand (to which the rust apparently traveled on the wind from eastern Australia). This evolution has been shown by Steele and others (2001) to have occurred in a stepwise fashion from an original single pathotype, with no subsequent new introductions. They also determined, through amplified fragment length polymorphism (AFLP) analysis, that the molecular changes have been small, indicating that the new pathotypes likely evolved from simple mutations rather than from parasexual recombination. [Note that even though the genetic changes in the pathogen populations are small (change of one gene?), they have resulted in infection of different wheat varieties and so are considered disease pathotypes or strains.]

Both these examples indicate that mutations have occurred and have proliferated through strong selection for increased virulence in response to development and planting of genetically homogeneous resistant varieties of wheat mostly within the past 30 to 50 years. Steele and others (2001) state that although somatic recombination of whole nuclei during germ-tube fusion has been produced in the laboratory for $P$. striiformis, there has been no verification that it actually occurs in the field. Coffee rust (Hemileiea vastatrix) also demonstrates the occurrence of evolution of variation in clonal fungi within just a few years after rust invasions of certain coffee growing areas (Do Ceu Silva and others, 2006).

Thus there is potential for evolution of stronger virulence in Hawaii's apparently asexual population of $P$. psidii, even without introduction of new genetic material. However, new asexual or sexual strains could greatly expand opportunities for development of and selection for a strain of pathogen that could spread through the large, contiguous patches of the 400,000 ha of Metrosideros polymorpha forest in Hawaii.

\section{Potential for Additional Genotypes/ Strains of $\boldsymbol{P}$. psidii and Other Serious Pests to Arrive and Establish in Hawaii}

P. psidii has become established in Hawaii at least once (in early 2005), so there is little doubt that it can do so again. Given the questionable effectiveness of the complex web of national and international phytosanitary approaches that has evolved for dealing with fungi (for example, Brasier 2008), one might question whether there is any way to keep more strains from arriving. Rossman (2009) described the difficulty:

One reason that fungi pose such a problem as invasive species is that most fungi are composed of hyphae, which are very narrow threadlike structures only $5-10 \mu \mathrm{m}$ diameter, thus the body of the fungus itself occurs inside the substratum and may not be visible from the outside. Only when the fungus is sporulating, often after the plant starts dying, can a fungal pathogen be detected by those who are inspecting agricultural commodities. [Note: One micrometer or one micron $(1 \mu \mathrm{m})=$ one thousandth of a millimeter $(\mathrm{mm})$ or one millionth of a meter.]

The difficulty is magnified by the fact that 150,000 fungal species have been described, and it is estimated that about 1.5 million species of fungi are likely to exist. As a result of the difficulty, only two dozen species of fungi are currently considered actionable organisms at ports of entry to the United States by USDA (Rossman and others, 2006, Rossman 2009). P. psidii was on such a list until it was established in Florida in the 1970 s, but even a fungal pathogen that is documented as dangerous generally becomes nonactionable and nonreportable as soon as it is established in the United States.

\section{What are the Potential Pathways for Entry of P. psidii into Hawaii?}

There are several pathways by which P. psidii could reach Hawaii from infected areas. These pathways have been described for Australia (Grgurinovic and others, 2006), and the same pathways likely apply in general for Hawaii. Grgurinovic and others (2006) noted that urediniospores of P. psidii can remain viable for at least 2 months outside hosts under suitable environmental conditions. They stated that potential pathways include:

1. High risk material of Myrtaceae species: movement of host plants, germ plasm, and plant products, including seed and pollen, micro propagation material and tissue culture, cuttings and live plants, and lumber, wood chips, and dunnage;

2. Unregulated movement of plant material: undeclared seed, nursery stock, and other material;

3. Movement of people: as contaminants on clothing and luggage of people traveling from infested areas; and

4. Long distance dispersal by air currents.

Although much is known about $P$. psidii and the threat it poses, our knowledge about pathways has been and continues to be imperfect. For example, we do not know precisely how and from where Hawaii's existing strain was introduced. The most current knowledge suggests that the most likely pathway of entry of P. psidii into Hawaii is by nursery stock or foliage of Myrtaceae. P. psidii is widely distributed in south Florida and has been established on myrtle (Myrtus communis) in San Diego County, California, at least since November 2005 (Mellano, 2006). Shipments of myrtle have commonly come to 
Hawaii from California (Janice Uchida, University of Hawaii, oral commun., 2007); therefore, this is a likely source of infection. Maui HDOA inspectors intercepted the rust on myrtle from California shippers several times during December 2006 to June 2007. Timothy Tidwell, Plant Pathologist with the California Department of Food and Agriculture, stated in a April 17, 2007, email that, "We have detected this rust species from samples originating from San Diego on Eugenia myrtifolia [= Syzygium paniculatum Gaertner], and what appears to be an interception on unspecified nursery stock shipped from FL. We also have a record of it from LA on an intercepted shipment of allspice plants (Pimenta dioica)." Additional interceptions of $P$. psidii on foliage from California were made during Hawaii's 12-month interim rule regulating movement of Myrtaceae. No information is available about $P$. psidii on nursery stock, although nursery stock is obviously another likely source.

\section{The Myrtaceae Flower/Foliage Pathway and P. psidii}

The flower/foliage trade has expanded remarkably over the past two decades, bringing billions of flowers annually into the United States from foreign countries. Pesticides are frequently applied liberally to these crops to avoid rejection at agricultural inspection stations at the U.S. border (Stewart, 2007). The domestic flower trade flourishes as well. Fungal infections, especially rusts, are notably prevalent and damaging in the flower trade, given that these pathogens cannot be adequately detected on asymptomatic but contaminated or infested plant material entering the United States or moving state to state (Wise and others, 2004). Fungicides are currently used in a Federal quarantine for chrysanthemum white rust (Puccinia horiana) in the nursery trade; they can potentially reduce but are not likely to eliminate opportunity for spread (Wise and others, 2004; Glen and others, 2006).

A number of internet sites indicate that there is geographic reshuffling of flowers and foliage among the farflung firms in the trade, especially for bouquet making. Because P. psidii is a nonregulated pest in the United States, foliage and flowers of the myrtle family can apparently move freely into the United States and from state to state. Rust spores can survive for 2 to 3 months (see Spore Longevity, below), allowing ample time for successful introduction of new strains to Hawaii.

For example, there is a wholesale business on the East Coast that advertises on the internet that it can supply waxflowers (Chamelaucium uncinatum) and myrtle (Myrtus communis) during any month of the year and ship them anywhere. Where do the wholesale flowers come from? "We buy flowers from the finest growers throughout the world including Central America, South America, Europe, and the United States. Our growers must meet our high standards for quality and consistency and are regarded as the finest in the industry. You can be sure that you are getting the best flowers in the world with every order!" Similarly, a West Coast-based wholesale florist advertises as "a direct shipper and wholesale supplier of high-quality cut flowers from around the world, including the United States"; it has "over 12 locations throughout the U.S." There is nothing illegal about these mainstream businesses. However, these operations clearly have potential for serving for Puccinia psidii and other fungi as "transport hubs," a situation recognized as providing options for "stepping stone" invasions of invasive species (Floerl and others, 2009).

Importers of flowers/foliage in Hawaii currently can order from a company anywhere in the United States as price dictates. California markets 75 percent of the flowers/foliage grown commercially in the United States and is the nearest source of Myrtaceae (primarily juvenile Eucalyptus foliage, myrtle, and waxflower) for Hawaii. Currently, "California supplies approximately 20 to 25 percent of all cut flowers sold in the United States with the balance being imported from South American countries" (California Cut Flower Commission, http://www.ccfc.org).

The cut foliage trade of Myrtaceae has been implicated as a pathway into Hawaii from California based on interceptions of P. psidii on Myrtus communis by HDOA and observed infection of waxflower on Maui, both in gardens and on cut flowers in a store. However, no P. psidii infections have yet been observed on imported juvenile Eucalyptus leaves, which have constituted the bulk of Myrtaceae foliage shipments in recent years. The foliage industry in Australia uses at least eight species: Eucalyptus cinerea, E. cordata, E. crenulata, E. gunnii, E. parvula, E. pulverulenta, E. bridgesiana, and E. nicholii (Barber and others, 2003). The market is based on the attractive juvenile growth of species with oval waxy leaves that have a silvery sheen. The widely adopted method of coppicing the trees to obtain the more attractive juvenile foliage results in younger, softer juvenile growth that is likely to be more susceptible to foliar pathogens (Barber and others, 2003). All eight of the species mentioned above have been found to be attacked by numerous native fungal pathogens in Australia, potentially resulting in serious impacts on economic yield because of disfigurement of leaves (Barber and others, 2003).

Further insight of generic hazards of the cut foliage pathway from California is provided by the example of Australian eucalypt insects establishing in New Zealand by Withers (2001): “[A] regulative loophole allowed the importation of untreated cut Eucalyptus foliage for the flower industry [from Australia] into New Zealand for some years up until 1999 . . Although all such foliage imports are inspected for the presence of unwanted organisms, inconspicuous life stages such as eggs and nymphs or young larvae of phytophagous insects may have passed the border controls undetected. It is not clear how long this particular loophole in New Zealand's biosecurity net remained open." (Hitchhiking fungal pathogens are of course equally or even more cryptic than insect pests.) 
Cut foliage is a potential pathway for many pests of Myrtaceae, both insects and pathogens. Fortunately, relatively few of the many Myrtaceae pests established in California have already reached Hawaii. California's Eugenia psyllid, Trioza eugeniae (Hemiptera: Psyllidae), would seem a very likely threat to Hawaii's ohia, as it notably attacks Metrosideros excelsa (a New Zealand native, very similar to ohia) as well as Syzygium paniculatum in suburban California, distorting young leaves, leading to reduced growth and dieback of twigs. Chrysophtharta m-fuscum, a Eucalyptus tortoise beetle, is a major pest of many Eucalyptus species, including E. globulus and E. pulverulenta (both important in Hawaii) in California. Mycosphaerella molleriana, not yet present in Hawaii, is a fungal (ascomycete) agent causing serious damage ("crinkle leaf disease") of young leaves of many Eucalyptus species in California.

Other serious Eucalyptus/Myrtaceae pests, widely established in the world due primarily to Eucalyptus forestry, will likely reach California soon and pose further threats to Hawaii through the foliage and nursery trade. Perhaps the most imminent of these is Leptocybe invasa, the blue gum chalcid wasp (Hymenoptera: Chalcidae) that induces galls on the midribs, petioles, and stems of new shoots of Eucalyptus trees. Heavy infestations can lead to deformed leaves and shoots and a growth reduction of the tree. L. invasa represents the phenomenon of new pests spreading out of Australia with the Eucalyptus forest industry and being described as new species elsewhere before even being discovered in Australia. It was found in the Middle East and Mediterranean region in 2000 and described in 2004 as a new species in a new genus (Mendel and others, 2004). It has since been found in several parts of its native Australia. Current known distribution includes Europe, Asia, and Africa; its known hosts include several of the Eucalyptus species in the foliage trade (European and Mediterranean Plant Protection Organziation, 2009). L. invasa was first recorded in the United States in Broward County, Florida, in July 2008 (Wiley and Skelley, 2008). Biocontrol has been already implemented with reported success in Israel and environs (Kim and others, 2008), but biocontrol is much less likely to be a viable option for Hawaii where native insects are associated with native Myrtaceae. The same problem holds for developing biocontrol agents for all the Myrtaceae pests for which biocontrol has been successfully developed in California (Van Driesche, 2008).

Ploetz and others (2008) reported the fungal pathogen, cf. Neofusicoccum parvum (Botryosphaeriaceae), causing serious damage to Syzygium paniculatum in south Florida nurseries. Previously (prior to 2005), Syzygium paniculatum (an Australian species) in south Florida had been free of pest problems, apparently not affected by $P$. psidii (although $S$. paniculatum is strongly affected by the $P$. psidii genotype in Hawaii). This fungus in south Florida nurseries appears to be a very serious pathogen capable of travel to and causing serious damage in Hawaii through the Myrtaceae nursery and foliage trade. Its demonstrated broad host range among Myrtaceae obviously provides cause for much concern in Hawaii.
More detail is given in the appendix on the apparent risk to Myrtaceae in Hawaii of these selected insect pests and pathogens.

\section{Spore Longevity}

Urediniospores of P. psidii remain viable for roughly 3 months under conditions they are likely to encounter during the transport of flowers/foliage:

Knowledge of the potential survival time of the different spore types is vital to assessing the risk associated with various pathways possible for an incursion .... In current studies, urediniospores from Eucalyptus spp. maintained viability after 90 days at $15^{\circ} \mathrm{C}$ and $35-55$ percent relative humidity, but only for 10 days at 35 or $40^{\circ} \mathrm{C}$ (V.M. Lana, E.A.V. Zauza and A.C. Alfenas, unpubl. data). The survival of urediniospores during a sea voyage from South America to Australia, with temperatures around $30^{\circ} \mathrm{C}$ and 70 percent $\mathrm{RH}$, is therefore likely to be low. (Glen and others, 2007, p. 6)

However, Biosecurity Australia (2007) noted that viable spores of P. psidii have been found on a shipment of wood imported to Australia from Brazil:

It is known that viable urediniospores of a member of the Puccinia psidii complex were imported to Australia from Brasil in 2004. Viable urediniospores were found on the outer wall of the shipping container, on plastic wrapping around the eucalypt timber, and on the surface of the kiln dried timber. Factories producing wood based panels, paper pulp, paper and paperboard are often located in close proximity to sawmills and close to eucalypt or other myrtaceous or amenity plantings. All wood based products may be shipped from the same export port. There is no reason why that forest products besides sawn timber would not be contaminated with viable urediniospores.

\section{Potential for Urediniospores of $\boldsymbol{P}$. psidii on Foliage or Flowers to Establish a Population in Hawaii}

Kliejunas (2001) rated the "colonization potential" of P. psidii from unprocessed Eucalyptus logs and chips from South America (in bark crevices or on attached leaf tissue) as "moderate":

Even though P. psidii has successfully established in locations outside its native distribution, the environmental requirements needed by the pathogen for infection to occur would limit colonization potential. Inoculum would have to reach susceptible species of Myrtaceae, and favorable environmental conditions (free water; temperatures between $18^{\circ} \mathrm{C}$ and $23^{\circ} \mathrm{C}$ ) 
would have to occur for infection and colonization to take place. Therefore, the colonization potential is rated as moderate. The rust has demonstrated ability to utilize new hosts within the Myrtaceae.

Biosecurity Australia (2007) also rated "probability of distribution," the likelihood that members of the P. psidii complex will be distributed in Australia with the importation of cut flowers and foliage of non-host species contaminated with guava rust spores as "moderate," although probability of rust spores arriving on cut flowers and foliage of non-host species contaminated with guava rust was considered "low":

Imported cut flowers and foliage would be distributed through wholesale markets or wholesalers located in capital cities. Most imported cut flowers would be retailed in urban areas in metropolitan, suburban and country areas.

Cut flowers are discarded when they start to wilt or fade. Many local governments discourage disposal of 'green waste' to municipal deep burial garbage disposal sites. Thus, a proportion of cut flowers will be discarded to compost bins or used as mulch in gardens. Another significant market for cut flowers is bunches and wreathes for use in cemeteries.

In general, all else being equal, cut flowers and foliage infected with plant pathogens are understandably considered much lower risk than "plants for planting" (nursery stock), because nursery stock provides a living platform for sustained proliferation of the pathogen. Nevertheless, in the case of $P$. psidii establishment in Hawaii, it was assumed early on that juvenile Eucalyptus leaves were the prime suspects because of the overwhelmingly large volume and difficulty of inspection. Later, when P. psidii was repeatedly intercepted on myrtle (Myrtus communis) by HDOA inspectors on Maui (Loope and La Rosa, 2008) and infected waxflowers (Chamelaucium uncinatum) were observed at a local retail store (F. and K. Starr, oral commun., 2007), it was assumed that cut material of those two species were the most likely sources of the established invasion. The hypothesis is supported by the fact that $P$. psidii present on Maui infects both myrtle and waxflower in outdoor gardens. That hypothesis is of course impossible to prove. Nevertheless it is clear that $P$. psidii established by some pathway, and moderately strong evidence points to the foliage and flower pathway. The "smoking gun" evidence exists only for foliage of Myrtus communis.

\section{Hawaii Department of Agriculture Mandate}

“The Hawaii Department of Agriculture's Plant Quarantine Program began over a hundred years ago when, in 1888, King David Kalakaua decreed that in order to protect the coffee industry in Hawaii, new coffee plants would not be allowed into the islands."

(HDOA Plant Quarantine Program homepage,

http://hawaii.gov/hdoa/pi/pq)

This was a time when coffee rust was spreading around the world with devastating consequences. For example, the Philippines was the world's fourth largest exporter of coffee in 1889, the year the coffee rust (Hemileia vastatrix) was first detected there. Then between 1889 and 1892, Philippine coffee exports dropped from 16 million pounds to virtually nothing (McCook, 2006). One of HDOA's greatest accomplishments has been success in keeping coffee rust out of Hawaii, now for more than 120 years. No other major coffeegrowing location in the world has achieved this. The strategy used has been a strict quarantine on coffee and coffee plants, aided by USDA. In 2005, regulations were modified to allow importation of unroasted coffee into Hawaii under a rigorous program in which treatment by either moist heat or ethylene bromide is implemented (USDA, 2005). Coffee rust continues to be a very serious impediment to coffee production worldwide (Do Ceu Silva and others, 2007; Ploetz, 2007). Hawaii's quarantine has also prevented many other notable coffee pests from arriving.

Today, HDOA's Plant Quarantine program is Hawaii's "first line of defense" in keeping pests out of the islands to protect the State's people and the environment. There is no question about the fact that Hawaii's overwhelmingly dominant Metrosideros forest is one of most important items of environmental value needing protection.

There is also a threat to commercial forestry from P. psidii. Plantations of Eucalyptus saligna, E. robusta, and E. grandis, varying in age from 15 to 60 years, are grown commercially on approximately 20,000 acres of private and 8,000 acres of Stateowned lands. Although E. saligna and E. robusta are known hosts for the disease in Brazil, commercial Eucalyptus forests in Hawaii have not yet been affected. Many of these acres are scheduled for thinning or harvesting in the next several years, and if replanted, could result in many acres of seedling and sapling Eucalyptus being available for infection.

\section{Regulatory Options}

As the trade in plants and plant products has increased, the conundrum of what phytosanitary rules are allowable or not allowable has presented formidable challenges to political entities that want to protect their natural heritage. In Hawaii, the potential consequences of a virulent strain of rust on ohia forests are immense, due to the role of ohia as a foundation tree species and the diversity of niches it fills. Although there is a relatively effective suite of standard options in quarantine entomology for mitigating the risk of pest introduction (for example, Follett and Neven, 2006), fewer opportunities seem to exist for effective mitigation of the threat of introduction of plant pathogens (for example, Rossman, 2009). 
Our understanding of the network of commercial and potential noncommercial pathways (see earlier section, Potential for Additional Genotypes/Strains of P. psidii, as well as Other Serious Pests, to Arrive and Establish in Hawaii Through the Foliage/Nursery Trade) for new strains of the rust to arrive in Hawaii is less than perfect. There can never be 100 percent certainty of keeping new strains out. However, the rust is not currently established in foreign countries that send plants and plant products directly to Hawaii. Therefore, a good opportunity exists for the State to enact protective quarantine measures within its mandate that have a good chance in the short run of stopping indirect shipments of infested foreign material shipped through mainland United States. Hawaii could maximize chances of keeping out new strains of $P$. psidii by prohibiting the importation of all plants and plant products in Myrtaceae coming by way of mainland United States.

Interdiction, which has effectively kept coffee rust (Hemileia vastatrix) out of Hawaii for more than a century, offers the strongest protection for Hawaii's native ecosystems. Prohibition of Myrtaceae provides a means of keeping out $P$. psidii as well as other significant pests of native and nonnative Myrtaceae (details in appendix). There would likely be a need to mitigate complete prohibition, through providing a means for bringing "germ plasm" of certain Myrtaceae in Hawaii in by permit. This may apply to Eucalyptus spp. for forestry (see Wingfield and others, 2008, for a good discussion of the risk), as well as to new Myrtaceae for Hawaii's green industry. Use of a molecular diagnostic test (see below) may be warranted in such instances, although such a test would not stop other serious Myrtaceae pests. Effectiveness of post-entry quarantine under permit could be explored by HDOA; Hawaii has decades of operational experience with such quarantines.

Subjecting all Myrtaceae imports into Hawaii to a molecular diagnostic test for $P$. psidii, such as the test developed by Langrell and others (2008) (discussed briefly above), could provide an alternative means of providing a high probability of excluding $P$. psidii. The Australian biosecurity authority considers the test accurate for detecting the presence of $P$. psidii, even when only small quantities of the rust are present. Such a test could be effective but is unlikely to prove practical because cost and the time required to process samples would likely preclude routine use at ports of entry. Furthermore, there appears to be no practical means of developing tests for individual genotypes or strains of $P$. psidii.

Currently, HDOA requests that plant material in the family Myrtaceae coming from mainland United States be presented at the port of entry into Hawaii and subjected to visual inspection for the purpose of detecting $P$. psidii or other pests. The occurrence of latent infections seriously limits the ability of inspectors to detect the rust by visual inspection.

Other options for regulating Myrtaceae might be at least partially effective, such as requiring pest-free production areas, pest-free production sites, State certification programs involving phytosanitary certificates, and (or) fungicide treatments. Effectiveness of any of these options could be increased by concurrent use of a molecular diagnostic test for $P$. psidii, such as the test developed by Langrell and others (2008). However, such options seem to be of only theoretical significance given that $P$. psidii is considered by USDA-APHIS (and hence by all States) as an unreportable pest. Hawaii had no advance warning that guava rust was in California and/or transported by the foliage/flower trade when it arrived in April 2005 and is unlikely to receive any warning of the existence anywhere in the United States of other strains of $P$. psidii.

There remains the lack of a mandate for the State of Hawaii to regulate pests from foreign countries. That mandate lies with USDA-APHIS. This is not necessarily an immediate concern, but the rust will eventually spread to countries that export directly to Hawaii.

Hawaii's ability to obtain protection from $P$. psidii from foreign countries may depend on its taking regulatory action through State quarantine, a point made clearly by Alontaga (2008):

Requests for further restriction of Myrtaceae in foreign import quarantines, based on the risk of introducing new strains of Puccinia psidii, would be directed to APHIS. However, currently P. psidii is known to occur in the United States and is categorized (by APHIS) as a non-reportable pest at the species level. The status does not distinguish between strains of $P$. psidii. This is important because APHIS would not regulate Myrtaceae for a non-reportable pest. A key factor to consider for changes to the pest status of $P$. psidii involves the obligations of the United States as a signatory of the International Plant Protection Convention (IPPC). The IPPC definition of quarantine pest is: “'Quarantine pest' —a pest of potential economic importance [this includes environmental impact] to the area endangered thereby and not yet present there, or present but not widely distributed and being officially controlled." The implication for prevention of $P$. psidii strains is to meet the pest definitions of limited distribution and official control. This is why state quarantine is important not only for protection from domestic movement, but also important for making progress for changes in regulation of foreign imports. If there are no state quarantine controls, the pest will not meet the IPPC definition of a quarantine pest.

Even if foreign import into Hawaii is restricted, restriction of domestic movement of Myrtaceae from the U.S. mainland will still play the major role in prevention of arrival of new strains of the rust. This is because APHIS restrictions on Myrtaceae and the reportability of the rust for Hawaii would be most effective for plant material entering Hawaii as the first port of entry. The pest would remain non-reportable to the other states where there is no official control. Major ports of entry for foreign plant material from major infestation areas in Central America, South America, and the Caribbean are the large mainland ports such as Los Angeles 
and Miami. There are no regular flights directly into Hawaii from these countries. Having entered the United States at one of the large ports, these shipments could then enter Hawaii as domestic movement. Hawaii regulation of Myrtaceae through state quarantine is a necessary prerequisite to pursuit of change in federal quarantine (APHIS) and is the only option for overall protection from future strains of $P$. psidii.

\section{Expected Economic Impacts of Stringent Regulation of the Myrtaceae Pathway}

Stringent regulation of the importation of Myrtaceae plants and plant parts into Hawaii would have an important long-term positive effect on the biodiversity conservation enterprise and maintenance of ecosystem services, entities which are vague and yet to be well defined and assessed in economic terms in Hawaii. It would have both positive and negative economic impacts on traditional businesses. For businesses centered on existing native or nonnative Myrtaceae already in Hawaii, such as the nonnative Eucalyptus forest industry, the status quo would be maintained with positive or neutral economic impacts anticipated. Many of the 28,000 acres of Eucalyptus plantations in Hawaii are scheduled for harvest in the next few years and replacement seedlings and saplings are potentially vulnerable to new strains of $P$. psidii. The Eucalyptus forest industry in Hawaii has not yet been affected by the rust, and prevention of rust damage would benefit this section of the forest industry.

For businesses involved in the importation of Myrtaceae plants and plant parts, some negative economic impacts would be anticipated. Although the potential volume of Myrtaceae foliage and perhaps live plants coming into Hawaii may be of significant importance to individuals, the overall economic impact of restrictions on Myrtaceae imports to Hawaii is expected to be small. This expectation is based on the assumption that other products can and will be substituted for Myrtaceae in the foliage trade and that Myrtaceae probably provides only a very small part of the Hawaii market for live plants. In the long run, it is expected that myrtaceous plants and foliage to be used in Hawaii can be grown in Hawaii and the potential for new local industries may offset losses experienced from a restriction on imports.

\section{Existing Framework for Addressing this Rust and an Available Option}

Agriculture has a standard, usually viable option, even for perennial crops, when quarantines for plant pathogens faildevelopment of resistant strains of the crop in question (for example, Ploetz 2007). The same is not the case for biodiversity conservation. Hawaii's Metrosideros polymorpha forest provides a classic example of the contrast between the needs of biodiversity conservation and those of those of agriculture/ forestry. Substantial effort has been expended in developing a research basis for breeding $P$. psidii resistant strains of Eucalyptus. In contrast, almost nothing is known about the genetics of M. polymorpha other than that great variation exists across broad environmental gradients. Nothing is known about the genetics of ohia in relation to resistance to P. psidii. It might be possible to breed a resistant strain of ohia, but the complexity of trying to develop resistant strains across broad environmental gradients is numbing, especially in the absence of commercial incentives.

In view of what may be considered a scarcity of hard information about $P$. psidii below the species level, one can turn to the documents of international law. Hedley (2004) has pointed out the significance of Principle 15 of the Rio Declaration on Environment and Development, which states:

In order to protect the environment, the precautionary approach shall be widely applied by States according to their capabilities. Where there are threats of serious or irreversible damage, lack of full scientific certainty shall not be used as a reason for postponing cost-effective measures to prevent environmental degradation. (United Nations Conference on Environment and Development, 1992, Principle 15).

Hedley also notes that the World Trade Organization Agreement on Sanitary and Phytosanitary Measures (SPS Agreement) makes a relevant policy statement with Article 5.7:

In cases where relevant scientific evidence is insufficient, a Member may provisionally adopt sanitary or phytosanitary measures on the basis of available pertinent information .... In such circumstances, Members shall seek to obtain the additional information necessary for a more objective assessment of risk and review the sanitary or phytosanitary measure accordingly within a reasonable period of time (World Trade Organization, 1994, p. 72).

Additionally, the first standard issued by the International Plant Protection Convention (IPPC), Principles of Plant Quarantine as Related to International Trade, states in item 14 relation to "emergency action":

Countries may, in the face of a new and/or unexpected phytosanitary situation, take immediate emergency measures on the basis of a preliminary pest risk analysis. Such emergency measures shall be temporary in their application, and their validity will be subjected to a detailed pest risk analysis as soon as possible. (Food and Agriculture Organization of the United Nations, 1997, p. 11)

Research funded by the U.S. Forest Service and others is underway in Brazil to determine the relative aggressiveness of P. psidii strains against ohia (Cannon and others, 2009). Logic suggests, and the international standards clearly permit, that 
the resource should be protected while this determination of risk is made.

Furthermore, the leadership for implementing the IPPC has worked toward harmonizing the IPPC with the international Convention on Biological Diversity (CBD; http://www. cbd.int/convention/convention.shtml, last accessed Nov. 18, 2009). (The United States is a signatory to the CBD but has not ratified it.) Supplement No. 2 to the International Standards for Pest Management (ISPM) No. 5 consists of "Guidelines on the Understanding Of Potential Economic Importance and Related Terms Including Reference to Environmental Considerations" (IPPC Secretariat, 2008):

The IPPC has historically maintained that the adverse consequences of plant pests, including those concerning uncultivated/unmanaged plants, wild flora, habitats and ecosystems, are measured in economic terms. References to the terms economic effects, economic impacts, potential economic importance and economically unacceptable impact and the use of the word economic in the IPPC and in ISPMs has resulted in some misunderstanding of the application of such terms and of the focus of the IPPC.

These guidelines clarify that the IPPC:

- can account for environmental concerns in economic terms using monetary or non-monetary values;

- asserts that market impacts are not the sole indicator of pest consequences;

- maintains the right of members to adopt phytosanitary measures with respect to pests for which the economic damage caused to plants, plant products or ecosystems within an area cannot be easily quantified.

They also clarify, with respect to plant pests, that the scope of the IPPC covers the protection of cultivated plants in agriculture (including horticulture or forestry), uncultivated/unmanaged plants, wild flora, habitats and ecosystems.

In April 2001 the ICPM [Interim Commission on Phytosanitary Measures] recognized that under the IPPC's existing mandate, to take account of environmental concerns, further clarification should include consideration of the following five proposed points relating to potential environmental risks of plant pests:

- reduction or elimination of endangered (or threatened) native plant species;

- reduction or elimination of a keystone plant species (a species which plays a major role in the maintenance of an ecosystem);
- reduction or elimination of a plant species which is a major component of a native ecosystem;

- causing a change to plant biological diversity in such as way as to result in ecosystem destabilization;

- resulting in control, eradication or management programs that would be needed if a quarantine pest was introduced, and impacts of such programs (e.g. pesticides or the release of non-indigenous predators or parasites) on biological diversity.

Thus it is clear, with respect to plant pests, that the scope of the IPPC covers the protection of cultivated plants in agriculture (including horticulture and forestry), uncultivated/unmanaged plants, wild flora, habitats and ecosystems.

Note that points 2 through 4 are highly applicable to Hawaii's ohia forest (keystone plant species, plant species which is a major component of a native ecosystem, causing a change to plant biological diversity in such as way as to result in ecosystem destabilization).

In conclusion, HDOA has a clear mandate for protecting Hawaii's environment, including its ohia forest. Based on the information cited and summarized in this report, it would seem that HDOA has the viable option of rigorous regulation of pathways to prevent arrival of additional strains of the rust fungus $P$. psidii. They also have the supplemental justification of protecting Hawaii from at least five other potentially serious pests of native and nonnative Myrtaceae already present in the United States but not in Hawaii. Regulation of Myrtaceae through State quarantine is a necessary prerequisite to pursuit of change in Federal quarantine through USDA-APHIS (see above), and given current procedural constraints, provides the only long-term option for reasonably comprehensive protection from new strains of $P$. psidii.

\section{Acknowledgments}

I thank USDA Forest Service plant pathologists Kerry Britton and Richard Sniezko, who assisted as reviewers and provided important guidance early in the process of producing this report. James Hendley of USGS provided major editing assistance late in the process. Janice Uchida, a plant pathologist with University of Hawaii at Mānoa, gave crucial information and professional encouragement. Forest and Kim Starr helped immensely with their photographic record and observations. Robert Anderson provided much information from his observations and data. Loyal Mehrhoff provided substantial encouragement and guidance. The following colleagues have made important contributions to the thoughts in this report, although some of them may not entirely endorse the findings: D. Alontaga, C. Buddenhagen, C. Buermeyer, F. Campbell, P. Cannon, P. Conant, M. Fox, J.B. Friday, S. Gon, R. Hauff, E. Killgore, A.M. La Rosa, M. Loope, C. Okada, and N. Reimer. 


\section{References Cited}

Aide, T.M., Zimmerman, J.K., Rosario, M., and MarcanoVega, H., 1996, Forest recovery in abandoned cattle pastures along an elevational gradient in northeastern Puerto Rico: Biotropica, v. 28, p. 537-548.

Agrios, G.N., 2005, Plant Pathology: New York, Academic Press, p. 140-145.

Aguilar, S., and Condit, R., 2001, Use of native tree species by an Hispanic community in Panama: Economic Botany, v. 55 , no. 2, p. 223-235.

Alfenas, A.C., Zauza, E.A.V., Wingfield, M.J., Roux, J., and Glen, M. 2005, Heteropyxis natalensis, a new host of Puccinia psidii rust: Australasian Plant Pathology, v. 34, p. 285-286.

Alontaga, D., 2008, What is the role of the U.S. Department of Agriculture (APHIS) in preventing additional strains of Puccinia psidii into Hawaii from other countries?, in Loope, L., and La Rosa, A.M., An analysis of the risk of introduction of additional strains of the rust Puccinia psidii Winter (ohia rust) to Hawaii: U.S. Geological Survey Open File Report 2008-1008, p. 8-9.

Andrade, A.C., 1951, O controle da ferrugem da goiabeira por meio de pulverizacoes: Arquivos do Instuto Biologico Sao Paulo, v. 20, p. 127-146.

Aparecido, C.C., Figueiredo, M.B., and Furtado, E.L., 2003, Groups of physiological variability in Puccinia psidii populations: Summa Phytopathologica, v. 29, p. 234-238.

Aradhya, K.M., Mueller-Dombois, D., and Ranker, T.A., 1993, Genetic structure and differentiation in Metrosideros polymorpha (Myrtaceae) along altitudinal gradients in Maui, Hawaii: Genetical Research, v. 61, p.159-170.

Barber, P.A., Smith, I.W., and Keane, P.J., 2003, Foliar diseases of Eucalyptus spp. grown for ornamental cut foliage: Australasian Plant Pathology, v. 32, p.109-111.

Bethke, J.A., Mellano, V.J., and Paine, T.D., 2006, A pest of landscape Eucalyptus in southern California becomes an ornamental pest: Healthy Garden-Healthy Home, University of California Cooperative Extension Retail Nursery Newsletter, v. 1, Issue 6, p. 3.

Biosecurity Australia, 2007, Pest risk analysis report for guava rust [draft]: Canberra, Biosecurity Australia.

Bishop Museum, 2002, Hawaiian Arthropod Checklist Database: Honolulu, Hawaii, Bishop Museum, accessed November 26, 2009, at http://www2.bishopmuseum.org/HBS/ checklist/query.asp?grp=Arthropod.
Borhidi, A., 1996, Phytogeography and Vegetation Ecology of Cuba, 2nd edition: Budapest, Hungary, Akademiai Kiado.

Bos, L., and Parlevliet, J.E., 1995, Concepts and terminology on plant/plant pest relationships - Toward consensus in plant pathology and crop protection: Annual Review of Phytopathology, v. 33, p. 69-102.

Brasier, C.M., 2008, The biosecurity threat to the UK and global environment from international trade in plants: Plant Pathology, v. 57, p. 792-808.

Broeker, K., Bernard, F., and Moerschbacher, B.M., 2006a, An EST library from Puccinia graminis $f$. sp. tritici reveals genes potentially involved in fungal differentiation: FEMS Microbiology Letters, v. 256, p. 273-281.

Broeker, K., Fehser, S., and Moerschbacher, B.M., 2006b, Survey and expression analysis of five new chitin synthase genes in the biotrophic rust fungus Puccinia graminis: Current Genetics, v. 50, p. 295-305.

Brown, K., Scatena, F.N., and Gurevitch, J., 2006, Effects of an invasive tree on community structure and diversity in a tropical forest in Puerto Rico: Forest Ecology and Management, v. 226, p. 145-152.

Bryan, G.T., Wu, K.-S., Farrall, L., Jia, Y., Hershey, H.P., McAdams, S.A., Faulk, K.N., Donaldson, G.K., Tarchini, R. and Valent, B., 2000, A single amino acid difference distinguishes resistant and susceptible alleles of the rice blast resistance gene Pi-ta: The Plant Cell, v. 12, p. 2033-2045.

Buermeyer, K., Loope, L., La Rosa, A.M., and Hauff, R., 2008, Ohia-Backbone of Hawaii's terrestrial ecosystems and culture: Poster presentation at International Union of Forestry Research Organizations, Conference on Invasive Species in International Trade, Shepherdstown, West Virginia, May 27-30, 2008, accessed November 26, 2009, at http://www.hear.org/species/metrosideros_polymorpha/pdfs/ buermeyeretalohiaposter20080527letter.pdf.

Burdon, J.J., and Silk, J., 1997, Sources and patterns of diversity in plant-pathogenic fungi: Phytopathology, v. 87, p. 664-669.

Cannon, P.G., Alfenas, A.C., and Britton, K.O., 2009, Understanding the potential of Guava Rust (Puccinia psidii) to destroy a Myrtaceous tree, Ohia (Metrosideros polymorpha), in Hawaii, in New Zealand Forest Research Institute Limited, compiler, Popular summaries: Rotorua, New Zealand, IUFRO International Forest Biosecurity Conference, 16-20 March 2009: NZFRI Bulletin, No. 233, p. 213-214.

Chen, X.M., 2005, Epidemiology and control of stripe rust (Puccinia striiformis f. sp. tritici) on wheat: Canadian Journal of Plant Pathology, v. 27, p 314-337. 
Ciesla, W.M., Diekmann, M., and Putter, C.A.J., 1996, FAO/ IPGRI Technical Guidelines for the Safe Movement of Germplasm. No. 17. Eucalyptus spp.: Rome, Food and Agriculture Organization of the United Nations, Rome/ International Plant Genetic Resources Institute. 66 p.

Coelho, L., Alfenas, A.C., and Ferreira, F.A., 2001, Physiologic variability of Puccinia psidii - the rust of Eucalyptus: Summa Phytopathologica, v. 27, p. 295-300.

Cordell, S., Goldstein, G., Meinzer, F.C., and Vitousek, P.M., 2001, Regulation of leaf life-span and nutrient-use efficiency of Metrosideros polymorpha trees at two extremes of a long chronosequence in Hawaii: Oecologia, v. 127, p. 198-206.

Cordell, S., Goldstein, G., Mueller-Dombois, D., Webb, D., and Vitousek, P.M., 1998, Physiological and morphological variation in Metrosideros polymorpha, a dominant Hawaiian tree species, along an altitudinal gradient - the role of phenotypic plasticity: Oecologia, v. 113, p. 188-196.

Cornwell, W.K., Bhaskar, B., Sack, L., Cordell, S., and Lunch, C.K., 2007, Adjustment of structure and function of Hawaiian Metrosideros polymorpha at high vs. low precipitation: Functional Ecology, v. 21, p. 1063-1071.

Coutinho, T.A., Wingfield, M.J., Alfenas, A.C., and Crous, P.W., 1998, Eucalyptus rust - a disease with the potential for serious international implications: Plant Disease, v. 82, p. $819-825$.

Cowie, R.H., and Holland, B.S., 2008, Molecular biogeography and diversification of the endemic terrestrial fauna of the Hawaiian Islands: Philosophical Transactions of the Royal Society of London, Series B, v. 363, p. 3363-3376.

Crawford, N.G., Hagen, C., Sahli, H.F., Stacy, E.A., and Glenn, T.C., 2008, Fifteen polymorphic microsatellite DNA loci from Hawaii's Metrosideros polymorpha (Myrtaceae: Myrtales), a model species for ecology and evolution: Molecular Ecology Resources, v. 8, p. 308-310.

Cuddihy, L.W., and Stone, C.P., 1990, Alteration of native Hawaiian vegetation - effects of humans, their activities and introductions: Honolulu, Hawaii, University of Hawaii Cooperative National Park Resources Studies Unit and University of Hawaii Press.

Dahlsten, D.L., Kent, D.M., Rowney, D.L., Copper, W.A., Young, T.E., and Tassan, R.L., 1995, Parasitoid shows potential for biocontrol of eugenia psyllid: California Agriculture, v. 49 , no. 4, p. 36-40.

Dahlsten, D.L., Rowney, D.L., and Copper, W.A., 1999, Eugenia psyllid biological control: University of California at Berkeley, Center for Biological Control, accessed November 26, 2009, at http://www.cnr.berkeley.edu/biocon/ dahlsten/eugenia/eug-web.htm.
Dawson, J.W., and Stemmerman, L., 1990, Metrosideros Banks ex Gaertn., in Wagner, W.L., Herbst, D.R., and Sohmer, S.H., eds., Manual of the Flowering Plants of Hawaii, Vol. 1: Honolulu, University of Hawaii Press, p. 964-970.

Deadman, M. L., 2006, Epidemiological consequesnces of plant disease resistance, in Cooke, B.M., Jones, D., Gareth, D., and Kaye, B., eds., The Epidemiology of Plant Disease: New York, Springer, p. 140-148.

Devey, M.E, Delfino-Mix, A., Kinloch, B.B., and Neale, D.B., 1995, Random amplified polymorphic DNA markers tightly linked to a gene for resistance to white pine blister rust in sugar pine: Proceedings of the National Academy of Science, v. 92, p. 2066-2070.

Di Stefano, J. F., Fournier, L.A., Carranza, J., Marin, W., and Mora, A., 1998, Potencial invasor de Syzygium jambos (Myrtaceae) en fragmentos boscosos - el caso de Ciudad Colon, Costa Rica: Revista Biologica Tropical, v. 46, p. 567-573.

Do Ceu Silva, M., Várzea, V., Guerra-Guimarães, L., Azinheira, H.G., Fernandez, D., Petitot, A.-S., Bertrand, B., Lashermes, P., and Nicole, M., 2006, Coffee resistance to the main diseases - leaf rust and coffee berry disease: Brazilian Journal of Plant Physiology v. 18, p. 119-147.

Downer, A.J., Koehler, C.S., and Paine, T.D., 1991, Biology and management of the Eugenia psyllid (Trioza eugeniae Froggatt): Journal of Environmental Horticulture, v. 9 no. 3, p. 137-141.

Ellison, A.M., Bank, M.S., Clinton, B.D., Colburn, E.A., Elliott, K., Ford, C.R., Foster, D.R., Kloeppel, B.D., Knoepp, J.D., Lovett, G.M., Mohan, J., Orwig, D.A, Rodenhouse, N.L., Sobczak, W.V., Stinson, K.A., Stone, J.K., Swan, C.M., Thompson, J., Von Holle, B., and Webster, J.R., 2005, Loss of foundation species: consequences for the structure and dynamics of forested ecosystems: Frontiers in Ecology and the Environment, v. 9, p. 479-486.

European and Mediterranean Plant Protection Organization, 2009, EPPO Alert List; Leptocybe invasa (Hymenoptera: Eulophidae), Blue gum chalcid: European and Mediterranean Plant Protection Organization, accessed November 26, 2009, at http://www.eppo.org/QUARANTINE/Alert_List/ insects/leptocybe_invasa.htm.

Food and Agriculture Organization of the United Nations, 1995, International Plant Protection Convention, New Revised Text, January 1999: Rome, Italy, Food and Agricultural Organization of the United Nations, accessed November 26, 2009, at https://www.ippc.int/id/13742?language=en

Farr, D.F., Rossman, A.Y. Palm, M.E., and McCray, E.B., 2006, Fungal Databases, Systematic Botany and Mycology Laboratory, United States Department of Agriculture, Agricultural Research Service, accessed November 26, 2009, at http://nt.ars-grin.gov/fungaldatabases/ 
Ferreira, F.A., 1983, Eucalyptus rust: Revista Arvore, v. 7, p. 91-109.

Ferreira, F.A., 1989,. Patologia forestal. Principais doencas florestais no Brazil: Vicosa, Brazil, Sociedade de Invetigacoes Florestais.

Figueiredo, M.B., 2001, Life cycle and ecology of Puccinia psidii: O Biologico, v. 63, p. 69-71.

Figueiredo, M.B., Coutinho, L.N., and Hennen, J.F., 1984. Estudos para determinacao do ciclo vital de Puccinia psidii: Summa Phytopathologica, v. 10, p. 53-54.

Figueiredo, M.B., and Hennen, J.F., 1998, Uredinales (ferrugens) no Brasil e estado de Sao Paulo: Biologico, v. 60, p. 17-29.

Flor, H.H., 1971, Current status of the gene-for-gene concept: Annual Review of Phytopathology, v. 9, p. 275-296.

Floerl, O., Inglis, G.J., Dey, K., and Smith, A., 2009, The importance of transport hubs in stepping-stone invasions: Journal of Applied Ecology, v. 46, p. 37-45.

Follett, P.A., and Neven, L.G., 2006, Current trends in quarantine entomology: Annual Review of Entomology, v. 51, p. 359-385.

Fosberg, F.R., 1948, Derivation of the flora of the Hawaiian Islands, in Zimmerman, E.C., ed., Insects of Hawaii, vol. 1: Honolulu, HI, University of Hawaii Press, p. 107-119.

Gaumann, E., 1959, Die rostpilze mitteleuropas: Bern, Switzerland, Kommissionsverlag Buchdruckerei Buechler.

Giambelluca, T.W., Diaz, H.F., and Luke, M.S.A., 2008, Secular temperature changes in Hawaii: Geophysical Research Letters, v. 35, p. L12702, doi:10.1029/2008GL034377.

Giambelluca, T.W., and Luke, M.S.A., 2007, Climate change in Hawaii's mountains: Mountain Views, v. 1, no. 2, p. 13-18, accessed November 26, 2009, at http://www. fs.fed.us/psw/cirmount/publications/pdf/Mtn_Views_ aug_07.pdf

Giambelluca, T., and Schroeder, T.A. 1998, Climate, in Juvik, J.O., Juvik, S.P., and Paradise, T.R., eds., Atlas of Hawaii: Honolulu, Hawaii, University of Hawaii Press, p 49-59.

Glen, M., Alfenas, A.C., Zauza, E.A.V., Wingfield, M.J. and Mohammed C., 2007, Puccinia psidii; a threat to the Australian environment and economy - a review: Australasian Plant Pathology, v. 36, no. 1, p.1-16.

Grgurinovic, C.A., Walsh, D., and Macbeth, F., 2006, Eucalyptus rust caused by Puccinia psidii and the threat it poses to Australia: EPPO Bulletin, v. 36, no. 3, p. 486-489.
Gruner, D.S., 2004, Arthropods from ohia lehua (Myrtaceae: Metrosideros polymorpha), with new records for the Hawaiian Islands: Bishop Museum Occasional Papers, v. 78, p. $33-52$.

Hawaii Department of Land and Natural Resources, 2005, Hawaii Comprehensive Wildlife Conservation Strategy, October 2005: 734 p.

Hayashi K., Hashimoto, N., Daigen, M., and Ashikawa, I., 2004, Development of PCR-based SNP markers for rice blast resistance genes at the Piz locus: Theoretical and Applied Genetics, v. 108, p. 1212-20.

Hedley, J., 2004, Chapter 7, The International Plant Protection Convention and invasive species, in Miller, M.L., and Fabian, R.N., eds., Harmful Invasive Species: Legal Responses: Washington, D.C., Environmental Law Institute, p. 185-201.

Hennen, J.F., Figueiredo, M.B., de Carvelho, A.A., and Hennen, P.G., 2005, Catalogue of the species of plant rust fungi (Uredinales) of Brazil: Rio de Janeiro, Brazil, Instituto de Pesquisas, Jardim Botanico do Rio de Janeiro.

Hodges, C.S., Adee, K.T., Stein, J.D., Wood, H.B., and Doty, R.D., 1986, Decline of Ohia (Metrosideros polymorpha) in Hawaii-Review: Berkeley, California, U.S. Department of Agriculture, Forest Service, Pacific Southwest Forest and Range Experiment Station.

Howarth, F.G., Sohmer, S.H., and Duckworth, W.D., 1988, Hawaiian natural history and conservation efforts-what's left is worth saving: BioScience, v. 38, no. 4, p. 232-237.

Hughes, R.F., and Denslow, J.S., 2005, Invasion by a N2-fixing tree alters function and structure in wet lowland forests of Hawaii: Ecological Applications, v. 15, p. 1615-1628.

IPPC Secretariat, 2004, ISPM No. 11, Pest risk analysis for quarantine pests, including analysis of environmental risks and living modified organisms (International Standards for Phytosanitary Measures): Rome, Italy, Secretariat of the International Plant Protection Convention, Food and Agricultural Organization (FAO) of the United Nations.

IPPC Secretariat, 2008, ISPM No. 5, Glossary of phytosanitary terms; includes Supplement No. 1 (2001)_Guidelines on the interpretation and application of the concept of official control for regulated pests, and Supplement No. 2 (2003) - Guidelines on the understanding of potential economic importance and related terms including reference to environmental considerations (International Standards for Phytosanitary Measures): Rome, Italy, Secretariat of the International Plant Protection Convention, Food and Agricultural Organization (FAO) of the United Nations. 
James, S.A., Puttock, C.F., Cordell, S., and Adams, R.P., 2004, Morphological and genetic variation in Metrosideros polymorpha (Myrtaceae) on Hawaii: New Zealand Journal of Botany, v. 42, p. 263-270.

Junghans, D.T., Alfenas, A.C., Brommonschenkel, S.H., Oda, S., Mello, E.J., and Grattapaglia, D., 2003, Resistance to rust (Puccinia psidii Winter) in Eucalyptus: mode of inheritance and mapping of a major gene with RAPD markers: Theoretical and Applied Genetics, v. 108, p.175-180.

Junqueira, N.T.V., de Andrade, L.R.M., Pereira, M., Lima, M.M., and da Chaves, R.C., 2001, Doenças da Goiabeira no Cerrado: Planaltina, DF, Brazil, Embrapa Cerrados, Circular Técnica, v. 15, p. 1-31.

Kaneshiro, K.Y. 1989. Uniqueness of Hawaii's biota, in Stone, C.P., and Stone, D.B., eds., Conservation Biology in Hawaii: Honolulu, HI, University of Hawaii Press for Cooperative National Park Resource Studies Unit, University of Hawaii, p. $7-10$.

Killgore, E.M., and Heu, R.A., 2005 [2007], Ohia rust. Puccinia psidii Winter: New Pest Advisory No. 05-04. Hawaii Department of Agriculture, updated March 2007.

Kim, I-K., Mendel, Z. Protasov, A., Blumberg, D., and La Salle, J., 2008, Taxonomy, biology, and efficacy of two Australian parasitoids of the eucalyptus gall wasp, Leptocybe invasa Fisher \& La Salle (Hymenoptera: Eulophidae: Tetrastichinae): Zootaxa, v. 1910, p. 1-20.

Kliejunas, J.T., 2001, Eucalyptus rust, in Kliejunas, J.T., Tkacz, B.M., Burdsall, H.H., Jr., DeNitto, G.A., Eglitis, A., Haugen, D.A., Wallner, W.E., eds., Pest risk assessment of the importation into the United States of unprocessed eucalyptus logs and chips from South America: Madison, Wisconsin, U.S. Department of Agriculture, Forest Service, Forest Products Laboratory, General Technical Report FPLGTR-124, p. 61-63.

Langrell, S.R.H., Glen, M., and Alfenas, A.C., 2008, Molecular diagnosis of Puccinia psidii (guava rust) - a quarantine threat to Australian eucalypt and Myrtaceae biodiversity: Plant Pathology, v. 57, p. 687-701.

Leahy, R., 2004, Recent history of Puccinia psidii on Myrtaceae in Florida: Florida Department of Agriculture and Consumer Services Division of Plant Industry.

Leppik, E.E., 1970, Gene centers of plants as sources of disease resistance: Annual Review of Phytopathology, v. 8, p. 323-344.

Loope, L.L., and Giambelluca, T.W., 1998, Vulnerability of island tropical montane cloud forests to climate change, with special reference to East Maui, Hawaii: Climatic Change, v. 39, p. 503-517.
Loope, L., and La Rosa, A.M. 2008, An analysis of the risk of introduction of additional strains of the rust Puccinia psidii Winter (ohia rust) to Hawaii: U.S. Geological Survey Open File Report 2008-1008. 11 p.

Lyons, S.W., 1982, Empirical orthogonal function analysis of Hawaiian rainfall: Journal of Applied Meteorology, v. 21, p. 1713-1729.

MacLachlan, J.D., 1936, The pimento rust disease: Journal of the Jamaica Agricultural Society, v. 40, p. 277-281.

MacLachlan, J.D., 1938, A rust of the pimento tree in Jamaica, BWI: Phytopathology, v. 28, p. 157-170.

Marin-Spiotta, E., Ostertag, R., and Silver, W.L., 2007, Longterm patterns in tropical reforestation-plant community composition and aboveground biomass accumulation: Ecological Applications, v. 17, p. 828-839.

Marlatt, R.B., and Kimbrough, J.W., 1979, Puccinia psidii on Pimenta dioica in south Florida: Plant Disease Reporter, v. 63 , p. $510-512$.

McCook, S., 2006, Global rust belt-Hemileia vastatrix and the ecological integration of world coffee production since 1850: Journal of Global History, v. 1, p. 177-195.

McIntosh, R.A., and Brown, G.N., 1997, Anticipatory breeding for resistance to rust diseases in wheat: Annual Review of Phytopathology, v. 35, p. 311-26.

Mellano, V., 2006, Rust on myrtle found in San Diego County: Healthy Garden-Healthy Home, University of California Cooperative Extension Retail Nursery Newsletter, v. 1, Issue 6, p. 3.

Mendel, Z., Protasov, A., Fisher, N. and La Salle, J., 2004, Taxonomy and biology of Leptocybe invasa gen. \& sp. n. (Hymenoptera: Eulophidae), an invasive gall inducer on Eucalyptus: Australian Journal of Entomology, v. 43, p. 101-113.

Millar, J.G., Paine, T.D., Bethke, J.A., Garrison, R.W., Campbell, K.A., and Dreistadt, S.H., 2009, Pest notes-Eucalyptus tortoise beetles: Davis, Calif., University of California, Agriculture and Natural Resources, Statewide IPM Program, Publication 74104.

Moon, D.H., Salvatierra, R.G.R., Caldas, D.G.G., Gallo de Carvalho, M.C.C., Carneiro, R.T., Franceschini, L.M., Oda, S., and Labate, C.A., 2007, Comparison of the expression profiles of susceptible and resistant Eucalyptus grandis exposed to Puccinia psidii Winter using SAGE: Functional Plant Biology, v. 34, p. 1010-1018.

Mueller-Dombois, D., 1985, Ohia dieback in Hawaii-1984 synthesis and evaluation: Pacific Science, v. 39, p. 150-170. 
Neelin, J.D., Munnich, M., Su, H., Meyerson, J.E., and Holloway, C.E., 2006, Tropical drying trends in global warming models and observations: Proceedings of the National Academy of Sciences, v. 103, p. 6110-6115.

Nyeko, P., Mutitu, E.K., and Day, R.K., 2007, Farmers' knowledge, perceptions and management of the gall-forming wasp, Leptocybe invasa (Hymenoptera: Eulophidae), on Eucalyptus species in Uganda: International Journal of Pest Management, v. 53 no. 2, p. 111-119.

Old, K.M., Wingfield, M.J., and Yuan, Z.Q., 2003, A manual for diseases of Eucalypts in SE Asia. Indonesia, Center for International Forestry Research, accessed November 26, 2009, at http://www.cifor.cgiar.org/publications/pdf_files/ Books/eucalypts.pdf

Paine, T.D., and Dreistadt, S.H., 2007, Pest notes; Psyllids: Davis, Calif., University of California, Agriculture and Natural Resources, Statewide IPM Program, Publication 7423.

Pavlic, D., Slippers, B., Coutinho, T.A., Wingfield, M.J., 2007, Botryosphaeriaceae occurring on native Syzygium cordatum in South Africa and their potential threat to Eucalyptus: Plant Pathology, v. 56, p. 624-636.

Percy, D.M., Garver, A.M., Wagner, W.L., James, H.F., Cunningham, C.W., Miller, S.E., and Fleischer, R.C., 2008, Progressive island colonization and ancient origin of Hawaiian Metrosideros (Myrtaceae): Proceedings of the Royal Society of London, Series B, v. 275, p. 1479-1490.

Ploetz, R.C., 2007, Diseases of tropical perennial crops: challenging problems in diverse environments: Plant Disease, v. 91, p. 644-663.

Ploetz, R.C., Pérez-Martínez, J.M., Palmateer, A.J., and Cating, R., 2008, Neofusicoccum parvum causes a lethal dieback of Syzygium paniculatum in Florida: British Society for Plant Pathology, New Disease Reports v. 18, accessed November 26, 2009, at http://www.bspp.org.uk/ publications/new-disease-reports/ndr.php?id=018022.

Pratt, T.K., 2009, Chapter 1, Origins and evolution, in Pratt, T.K., Atkinson, C.T., Banko, P.C., Jacobi, J.D., and Woodworth, B.L., eds., Conservation biology of Hawaiian forest birds - implications for island avifauna: New Haven, Conn., Yale University Press, p. 3-24.

Pratt, T.K., Atkinson, C.T., Banko, P.C., Jacobi, J.D., Woodworth, B.L., and Mehrhoff, L.A., 2009, Chapter 24, Can Hawaiian forest birds be saved? in Pratt, T.K., Atkinson, C.T., Banko, P.C., Jacobi, J.D., and Woodworth, B.L., eds., Conservation biology of Hawaiian forest birds-Implications for island avifauna: New Haven, Conn., Yale University Press, p. 552-580.
Price, J.P., and Clague, D.A., 2002, How old is the Hawaiian biota? - Geology and phylogeny suggest recent divergence: Proceedings of the Royal Society of London, Series B, v. 269, p. 2429-2435.

Price, J.P., and Wagner, W.L., 2004, Speciation in Hawaiian angiosperm lineages - cause, consequence, and mode: Evolution, v. 58, no. 10, p. 2185-2200.

Protasov, A., Blumberg, D., Brand, D., La Salle, J., and Mendel, Z., 2007, Biological control of the gall wasp Ophelimus maskelli (Ashmead) - Taxonomy and biology of the parasitoid species Clostocerus chameleon (Girault), with information on its establishment in Israel: Biological Control, v. 42, p. 196-206.

Protasov, A., La Salle, J., Blumberg , D., Brand, D., Saphir, N., Assael, F., Fisher, N., and Mendel, Z., 2007, Biology, revised taxonomy and impact on host plants of Ophelimus maskelli, an invasive gall inducer on Eucalyptus spp. in the Mediterranean area: Phytoparasitica, v. 35, no. 1, p. 50-76.

Rayachhetry, M.B., Van, T.K., Center, T.D., and Elliott, M.L., 2001, Host range of Puccinia psidii, a potential biological control agent of Melaleuca quinquenervia in Florida: Biological Control, v. 22, p. 38-45.

Rodrigues, C.J., Bettencourt, A.J., and Rijo, L., 1976, Races of the pathogen and resistance to coffee rust: Annual Review of Phytopathology, v. 13, p. 49-70.

Rossi, M., Goggin, F.L. Milligan, S.B., Kaloshian, I., Ullman, D.E., and Williamson, V.M., 1998, The nematode resistance gene Mi of tomato confers resistance against the potato aphid: Proceedings of the National Academy of Sciences, v. 95 , p. $9750-9754$.

Rossman, A.Y., 2009, The impact of invasive fungi on agricultural ecosystems in the United States: Biological Invasions, v. 11, p. 97-107.

Rossman, A.Y., Britton, K., Luster, D., Palm, M., Royer, M.H., and Sherald, J., 2006, Evaluating the threat posed by fungi on the APHIS list of regulated plant pests: Plant Health Progress, doi:10.1094/PHP-2006-0505-01-PS.

Ruiz, R.A.R., Alfenas, A.C., and Ferreira, F.A.,1989, Influencia de temperature, luz e origem do inoculo sobre a producao de urediniosporos e teliosporos de Puccinia psidii: Fitopatologia Brasiliera, v. 14, p. 70-73.

Schmelzer, E., 2002, Cell polarization, a crucial process in fungal defense: Trends in Plant Science, v. 7, p. 411-415.

Sherman, R.E., Martin, P.H., and Fahey, T.J., 2005, Vegetation-environment relationships in forest ecosystems of the Cordillera Central, Dominican Republic: Journal of the Torrey Botanical Society, v. 132, p. 293-310. 
Simon, C., 1987, Hawaiian evolutionary biology: an introduction: Trends in Ecology and Evolution, v. 2, p. 175-178.

Simpson, J.A., Thomas, K., and Grgurinovic, C.A. 2006, Uredinales species pathogenic on species of Myrtaceae: Australasian Plant Pathology, v. 35, p. 546-562.

Slippers, B., Stenlid, J. and Wingfield, M.J. 2005, Emerging pathogens - fungal host jumps following anthropogenic introduction: Trends in Ecology and Evolution, v. 20, p. $420-421$.

Slippers, B., and Wingfield, M.J., 2007, Botryosphaeriaceae as endophytes and latent pathogens of woody plants - diversity, ecology and impact: Fungal Biology Reviews, v. 21, p. 90-106.

Snow, N., 2008, Studies of Malagasy Eugenia (Myrtaceae) - I, Two new species from the Masoala Peninsula and generic transfers from Monimiastrum: Systematic Botany, v. 33, p. 343-348.

Staples, G.W., and Herbst, D.R., 2005, A Tropical Garden Flora: Honolulu, Hawaii, Bishop Museum Press.. 908 p.

Staples, R.C., 2000, Research on the rust fungi during the twentieth century: Annual Review of Phytopathology, v. 38, p. 49-69.

Steele, K.A., Humphreys, E., Wellings, C.R., and Dickinson, M.J., 2001, Support for a stepwise mutation model for pathogen evolution in Australasian Puccinia striiformis f.sp. tritici by use of molecular markers: Plant Pathology, v. 50, p. 174-180.

Stewart, A., 2007, Flower confidential—The good, the bad, and the beautiful in the business of flowers: Chapel Hill, North Carolina, Algonquin Books. 306 p.

Sultan, S.E., 2000, Phenotypic plasticity for plant development, function and life history: Trends in Plant Science, v. 5, p. 537-542.

Tessmann, D.J., Dianese, J.C., Miranda, A.C., and Castro, L.H.R., 2001, Epidemiology of a neotropical rust (Puccinia psidii)_periodical analysis of the temporal progress in a perennial host (Syzygium jambos): Plant Pathology, v. 50, p. $725-731$.

Thompson, J., Lugo, A.E., and Thomlinson, J., 2007, Land use history, hurricane disturbance, and the fate of introduced species in a subtropical wet forest in Puerto Rico: Plant Ecology, v. 192, p. 289-301.

Tommerup, I.C., Alfenas, A.C., and Old, K.M., 2003, Guava rust in Brazil - a threat to eucalyptus and other Myrtaceae: New Zealand Journal of Forestry Science, v. 33, no. 3, p. 420-428.
Uchida, J.Y., and Loope, L.L., 2009, A recurrent epiphytotic of guava rust on rose apple, Syzygium jambos, in Hawaii: Plant Disease, v. 93, p. 429.

Uchida, J., Zhong, S., and Killgore, E., 2006, First report of a rust disease on ohia caused by Puccinia psidii in Hawaii: Plant Disease, v. 90, p. 524.

United Nations Conference on Environment and Development, 1992, Rio Declaration on Environment and Development: accessed November 30, 2009, at http://www.unep. org/Documents.multilingual/Default.asp?DocumentID=78\& ArticleID $=1163$.

U.S. Department of Agriculture, 2005, Proposed rule for movement of unroasted coffee into Hawaii and Puerto Rico, Environmental Assessment, September 2005: U.S. Department of Agriculture, Marketing and Regulatory Programs, Animal and Plant Health Inspection Service.

Valladares, F., Gianoli, E., and Gómez, J.M., 2007, Ecological limits to plant phenotypic plasticity: New Phytologist v. 176, p. 749-763.

Van Driesche, RG., 2008, Chapter 5, Biological pest control in mix and match forests, in Paine, T.D., ed., Invasive forest insects, introduced forest trees, and altered ecosystems: Dordrecht, The Netherlands, Springer, Ecological Pest Management in Global Forests of a Changing World, p. 79-93.

Vitousek, P., 2004, Nutrient Cycling and Limitation: Hawaii as a Model System: Oxford, U.K., and Princeton, N.J., Princeton University Press. 223 p.

Warren, R.F., Henk, A., Mowery, P., Holub, E., and Innes, R.W., 1998, A mutation within the Leucine-rich repeat domain of the Arabidopsis disease resistance gene RPS5 partially suppresses multiple bacterial and downy mildew resistance genes: Plant Cell, v. 10, p. 1439-1452.

Wiley, J., and Skelley, P., 2008, Pest alert-a Eucalyptus pest, Leptocybe invasa Fisher and LaSalle (Hymenoptera: Eulophidae), genus and species new to Florida and North America: Florida Department of Agriculture and Consumer Services, accessed November 26, 2009, at http://www. doacs.state.fl.us/pi/enpp/ento/leptocybe_invasa.html.

Wilson, P.G., O’Brien, M.M., Heslewood, M.M., and Wilson, C.J.Q., 2005, Relationships within Myrtaceae sensu lato based on a matK phylogeny: Plant Systematics and Evolution, v. 251, p. 3-19.

Wingfield, M.J., 2003, 2003 Daniel McAlpine Memorial Lecture-Increasing threat of diseases to exotic plantation forests in the Southern Hemisphere, lessons from Cryphonectria canker: Australasian Plant Pathology, v. 32, p.133-139. 
Wingfield, M.J., Slippers, B., Hurley, B.P., Coutinho, T.A., Wingfield, B.D., and Roux, J., 2008, Eucalypt pests and diseases-growing threats to plantation productivity: Southern Forests (South Africa), v. 70, no. 2, p. 139-144.

Wingfield, M.J., Slippers, B., Roux, J., and Wingfield, B.D., 2001, Worldwide movement of exotic forest fungi, especially in the tropics and the Southern Hemisphere: BioScience, v. 51, p. 134-140.

Wise, K.A., Mueller, D.S., and Buck, J.W., 2004, Quarantines and ornamental rusts: APSnet Feature Story Feb. 2004, American Phytopathological Society, accessed November 26, 2009, at http://www.apsnet.org/online/feature/quarantine/.

Withers, T.M., 2001, Colonization of eucalypts in New Zealand by Australian insects: Austral Ecology, v. 26, p. $467-476$.
World Trade Organization, 1994, Agreement on the Application of Sanitary and Phytosanitary Measures, in The results of the Uruguay round of multilateral trade negotiations - the legal texts: Accessed November 30, 2009, at http://www.wto.org/english/docs_e/legal_e/15-sps.pdf.

Xavier, A.A., 2002, Histopatologia da interacao Puccinia psidii e virulencia de isolados do patogenoem especies de Myrtaceae: Federal University of Vicosa, Brazil, Ph.D. dissertation.

Zablan, M., 2007, Eugenia koolauensis (Nioi) - 5-year review summary and evaluation: Honolulu, Hawaii, U.S. Fish and Wildlife Service, Pacific Islands Fish and Wildlife Office.

Zhong, S., Yang, B., and Alfenas, A.C., 2007, Development of microsatellite markers for the guava rust fungus, Puccinia psidii: Molecular Ecology Notes, v. 8, p. 348-350. 


\section{Appendix. Sketches of Risk Assessments for Selected Insect Pests and Pathogens that Pose Significant Threats to Native and (or) Nonnative Myrtaceae in Hawaii}

\section{Trioza eugeniae Froggatt, Eugenia Psyllid}

The Eugenia psyllid, a native of Australia, was first discovered in the Los Angeles area in May 1988 and spread quickly all along coastal California from San Diego County to Napa County and Marin County. Feeding and damage occur on Syzygium paniculatum Gaertn. (=Eugenia myrtifolia), commonly known as the Australian bush cherry, which is used extensively in California as a hedge plant or small tree. The Eugenia psyllid has a very narrow host range, but damage has also been observed on juvenile foliage of Metrosideros excelsa, the New Zealand Christmas Tree (pohutukawa) in suburban southern California (Downer and others, 1991; Paine and Dreistadt, 2007).

The Eugenia psyllid has three to five plus overlapping generations, apparently determined in part by the interaction of temperature and the physiological state of the host plant. After mating, the female psyllid partially inserts yellow football-shaped eggs into the edges of the new terminal leaves. Small mobile nymphs hatch from the eggs and settle on the newly expanding leaves, primarily on the ventral surface, where they feed and develop in a cup-shaped pit or gall, formed by the plant's response to the psyllid's feeding. Psyllids produce honeydew, a sticky substance that falls on sidewalks and cars. Acute plant damage caused by high psyllid densities include inhibition of new shoot formation, distortion of foliage and stems, and a spoiled plant appearance as a result of the black sooty molds growing on the honeydew. In large quantities, honeydew can cause unpleasant effects on sidewalks and cars. Chronic effects of sustained high infestation are well documented and include severe weakening of plants, poor growth characteristics, and lowered economic value (Dahlsten and others, 1999).

Parasitoid wasps, Tamarixia sp. (Hymenoptera: Chalcidoidea), were found in 1991 in the native range of Syzygium paniculatum and Trioza eugeniae in southeast Australia and initially released in California in 1992. The parasitoids spread rapidly and had established in most coastal areas of the State by 1994 (Dahlsten and others, 1995).

Control by the parasitoid is apparently suboptimal. In cooler areas of the California coast, such as the city of San Francisco, the parasitoid populations were found to not increase quickly enough to respond to sudden increases in psyllid numbers. Dahlsten and others (1999) stated, "We may import new strains of the parasitoid or another parasitoid species to help control the psyllid in the future ....," but this apparently has not happened.

Biological control of Trioza engeniae, were it to get to Hawaii and cause significant damage, would be highly problematic, if not impossible, as there are 10 described endemic species of Trioza in Hawaii and at least two undescribed ones (Bishop Museum, 2002); some of them use Metrosideros polymorpha (Gruner, 2004).

\section{Chrysophtharta m-fuscum Boheman, Eucalyptus Tortoise Beetle (Coleoptera: Chrysomelidae)}

Two species of Eucalyptus leaf beetles from Australia, also called tortoise beetles, have been introduced into California. Trachymela sloanei was found in 1998 in Riverside County and now occurs throughout most areas of California where Eucalyptus trees grow. Chrysophtharta m-fuscum was discovered in Orange County in 2003 and has spread to at least four nearby counties.

Adult beetles and larvae chew semicircular holes or irregular notches along edges of Eucalyptus leaves. The beetles can remove most of a leaf's surface, leaving only the midvein, and they occasionally feed on new terminal growth. During heavy infestations, trees can lose most of their leaves, which increases tree stress. Although these beetles alone are not known to kill trees, their feeding adds to that of numerous other new Eucalyptus pests introduced into California during the past three decades. Combined stress from multiple pests can eventually lead to tree death, especially if growing conditions are not optimal.

Chrysophtharta m-fuscum is a major pest of Eucalyptus globulus in southeast Australia and in California. (E. globulus has been planted extensively in Hawaii.) It is also a serious pest of commercially grown Eucalyptus pulverulenta, baby blue or silverleaved mountain gum, commonly used as fresh cut foliage in flower arrangements. E. viminalis is another species hit particularly hard in California. No biocontrol has yet been developed for C. m-fuscum. (Summary from Bethke and others, 2006, and Millar and others, 2009.) 


\section{Leptocybe invasa Fisher and LaSalle, Blue Gum Chalcid (Hymenoptera: Eulophidae)}

Leptocybe invasa is a galling wasp described by Mendel and others (2004) as a new species in a new genus. Within the past decade, taxonomic confusion has reigned for serious invasive eulophid pests that have invaded Eucalyptus forests in the Mediterranean region and Southern Europe. Out of the confusion came two new species of gall-inducing wasps: Leptocybe invasa and Ophelimus maskelli. Currently, both species are causing severe damage to Eucalyptus, in particular to Eucalyptus camaldulensis, which is the most important species of Eucalyptus planted in the Mediterranean region and the Middle East. Although the taxonomy of Ophelimus is poorly known, it is now considered that the species that has been introduced into the Euro-Mediterranean region is Ophelimus maskelli and not $O$. eucalypti (which is an invasive species in New Zealand).

Leptocybe invasa induces galls on the mid-ribs, petioles and stems of new shoots of Eucalyptus trees. Mendel and others (2004) tested 36 species of Eucalyptus and found 10 to be suitable hosts: Eucalyptus camaldulensis, E. tereticornis, E. botryoides, E. grandis, E. robusta, E. saligna, E. bridgesiana, E. globulus, E. gunii, and E. viminalis. Heavy infestations can lead to deformed leaves and shoots and a growth reduction of the tree. Serious damage to young plantations and nursery seedlings has been reported, but tree mortality has apparently not been observed. L. invasa (as well as O. maskelli) represents the phenomenon of new pests spreading out of Australia with the Eucalyptus forest industry and being described as new species elsewhere before even being discovered in Australia. It was found in the Middle East and Mediterranean region in 2000 and described in 2004 as a new species in a new genus (Mendel and others, 2004). It has since been found in several parts of its native Australia. Current known distribution includes Europe (France, Corsica, Greece, Italy, Portugal, Spain, and Turkey), Asia (India, Iran, Israel, Jordan, Syria, Thailand, Turkey, and Vietnam), Africa (Algeria, Ethiopia, Kenya [2002], Morocco, South Africa [2007], Tanzania [2005], and Uganda [2002]); its known hosts include at least two of the Eucalyptus species in the foliage trade

(E. bridgesiana and E. gunii).

Leptocybe invasa was first recorded in the United States in Broward County, Florida, in July 2008 (Wiley and Skelley, 2008). Ophelimus maskelli, very similar to Leptocybe invasa, is not yet known in the United States but can be expected to be found here soon. Heavy leaf galling by $O$. maskelli results in premature shedding of the leaves soon after adult emergence. High populations of $O$. maskelli in Israel resulted in 80-year-old trees almost completely losing their foliage. Both $O$. maskelli and $L$. invasa have occurred at epidemic levels in Israel, and galls of the two species are often found on the same leaves. Observations in Israel tend to suggest that $O$. maskelli is a better competitor that could displace $L$. invasa. During peak emergence periods, $O$. maskelli can be a nuisance to humans by forming "clouds" of wasps (Protosov and others, 2006).

Two biological control agents for Leptocybe invasa, Quadrastichus mendeli and Selitrichodes kryceri (both Hymenoptera: Eulophidae), have been released and have established in Israel (Kim and others, 2008).

A biological control agent for Ophelimus maskelli, Closterocerus chameleon (Hymenoptera: Eulophidae), has been released in Israel (Protosov and others, 2007).

\section{Mycosphaerella molleriana (Thum.) Lindau (“Crinkle Leaf Disease") (Ascomycota: Mycosphaerellales: Mycosphaerellaceae)}

Mycosphaerella molleriana is known as a pathogen of plants in the Myrtaceae, such as Eucalyptus and Myrcia. Kliejunas and others (2003) list the following Eucalyptus species as host plants: Eucalyptus bridgesiana, E. cypellocarpa, E. globulus, E. gunnii, and E. viminalis. In Brazil, M. molleriana is known from Myrcia brasiliae (Farr and others, 2006).

Ciesla and others (1996) reported that although seed infection has not actually been documented, seeds may well be a means of long distance dispersal. The disease could be transported in infested materials, such as leaves or logs that have attached leaves, and to a lesser extent in wood chips (Kliejunas and others, 2003). In addition, propugules may survive and be transported in soils (Kliejunas and others, 2003). The disease is most common in summer rainfall areas and can be spread by water or wind (Ciesla and others, 1996, Kliejunas and others, 2003).

Mycosphaerella species are common in natural areas of Australia and are a pest of nurseries and forestry plantations. In Eucalyptus plantations, M. cryptica and M. molleriana are said to be the most common and most damaging species (Kliejunas and others, 2003). These have caused severe epidemics in temperate areas, such as New Zealand, Australia, and South Africa (Old and others, 2003). Damage from the disease includes foliage loss and reduced growth. Infection causes necrotic spots or patches and crinkled, dried out, distorted foliage, which results in premature leaf drop and stunted plants (Kliejunas and others, 2003). Spots start out yellowish-brown later becoming grey-black. Infection occurs on young and intermediate foliage only (Ciesla and others, 1996).

Mycosphaerella molleriana is native in Australia (in the states of Queensland, Southern Australia, Tasmania, and Victoria) (Kliejunas and others, 2003). Its introduced range includes Africa (Kenya, Malawi, Southern Africa, Tanzania, Zimbabwe), Europe (Portugal), South America (Brazil), North America (California), and Papua New Guinea (Farr and others, 2006). 


\section{Neofusicoccum parvum (Pennycook and Samuels) Crous, Slippers and A.J.L. Phillips (Ascomycota: Botryosphaeriales: Botryosphaeriaceae)}

Ploetz and others (2008) reported the fungal pathogen, cf. Neofusicoccum parvum (Botryosphaeriaceae), causing serious damage to Syzygium paniculatum in south Florida nurseries. The problem occurred in at least 20 different nurseries. Symptoms include wilting and death of terminal and lateral branches and extensive vascular discoloration. Previously (before 2005), Syzygium paniculatum (an Australian species) in south Florida had been free of pest problems, apparently not significantly affected by Puccinia psidii (although S. paniculatum is strongly affected by the P. psidii genotype in Hawaii).

Neofusicoccum parvum is a somewhat enigmatic entity known from South Africa, New Zealand and Australia. It may have originated on Syzygium in South Africa, where the species also attacks Eucalyptus spp., but N. parvum has also been found in New Zealand and Australia (Pavlik and others, 2007, Slippers and Wingfield, 2007). This fungus in south Florida nurseries appears to be a very serious fungal pathogen capable of travel to and serious damage in Hawaii through the Myrtaceae nursery and foliage trade. Its demonstrated broad host range among Myrtaceae obviously provides cause for much concern in Hawaii. 
Produced in the Western Region, Menlo Park, California Manuscript approved for publication March 10, 2010

Text edited by James W. Hendley II

Layout and design by Judy Weathers 
BACK COVER:

Clockwise from upper left: Roadside forest of ohia just within the north entrance to Hawaii Volcanoes National Park (courtesy of Forest and Kim Starr); P. psidii spores on leaves of ohia, Metrosideros polymorpha (courtesy of Robert Anderson, USGS); P. psidii spores on cultivated myrtle, Myrtus communis, Kula, Maui (courtesy of Forest and Kim Starr); P. psidii spores on cultivated Geraldton waxflower, Chamelaucium uncinatum, Kula, Maui (courtesy of Forest and Kim Starr); ohia forest, Kipahulu Valley, Haleakala National Park, Maui (courtesy of Arthur Medeiros, USGS). 


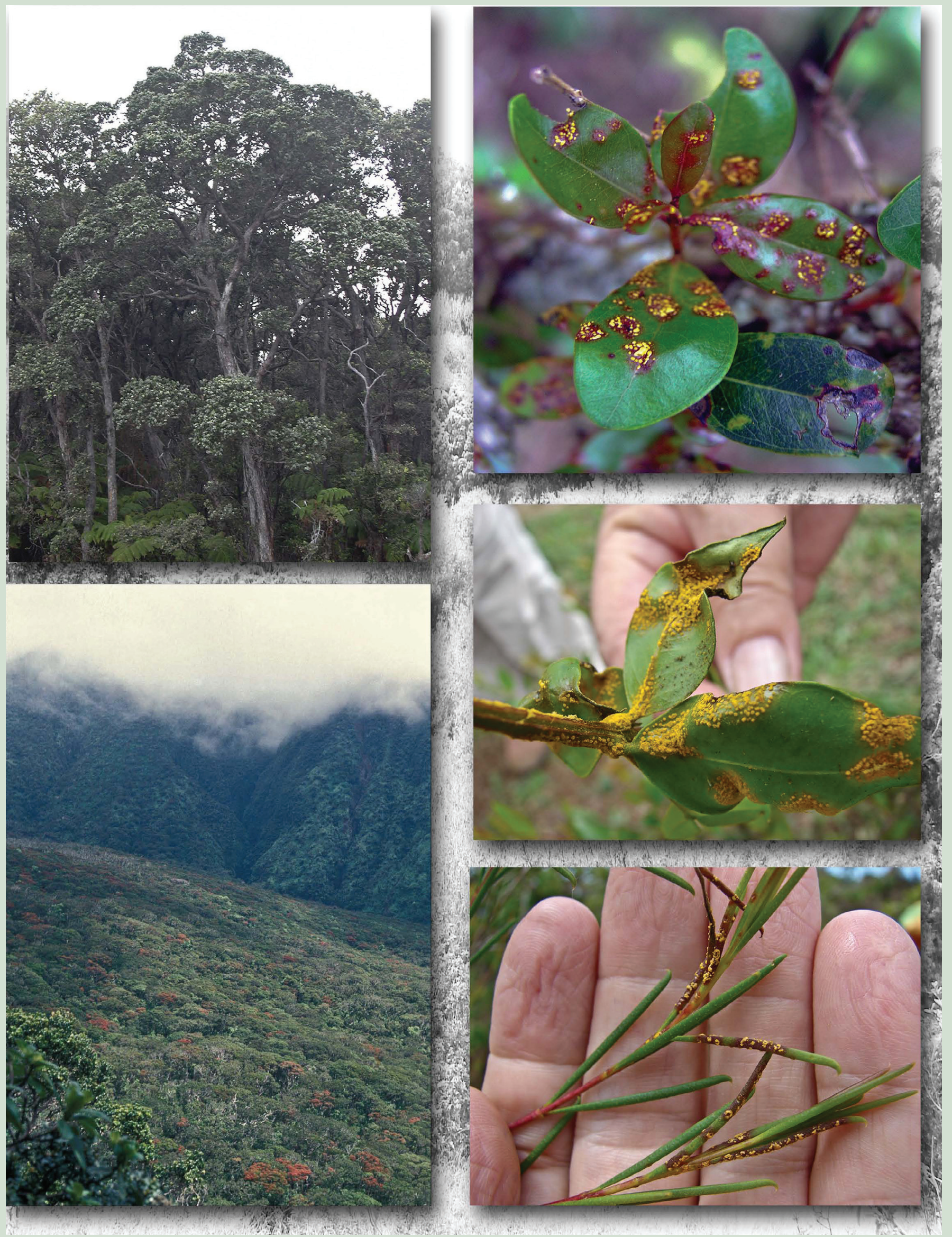

웅 